\title{
The use of fish metabolic, pathological and parasitological indices in pollution monitoring
}

\section{North Sea}

Received: 1 March 1999 / Received in revised form: 25 May 1999 / Accepted: 7 June 1999

\begin{abstract}
An integrated biological effect monitoring concept has been tested in flounder (Platichthys flesus L.) from four locations with different anthropogenic impact in the German Bight. During 3 years of sampling, biomarkers at all levels of biological organisation from the molecular to the ecosystem level were applied and tested on 742 individual fish of body lengths between 18 and $25 \mathrm{~cm}$. At the ecosystem level, the fish were taken as a habitat for the parasite assemblage. The hypothesis was that changes in the environment might lead to changes in the species diversity of parasites and in the infection intensity of single species, as well as between heteroxenic and monoxenic parasite species (H/M ratio). At the molecular level, activity of the CYP1A-dependent monooxygenase ethoxyresorufin O-deethylase (EROD) was used as a biomarker of exposure. At the subcellular level, the integrity of lysosomal membranes in hepatocytes was taken as an indicator of non-specific acute and chronic toxic effects. Both biomarkers are recommended by the ICES Advisory Committee on the Marine Environment for the application in biological effects monitoring programmes. In addition, neutral lipid content in the liver was used as a marker for pathologically induced fat accumulation. In the same individual fish, a new method for the measurement of macrophage aggregate activity in
\end{abstract}

K. Broeg $(\bullet) \cdot$ G. Krüner · H. v. Westernhagen

Biologische Anstalt Helgoland,

Alfred Wegener Institut für Polar- und Meeresforschung,

Notkestrasse 31, D-22607, Hamburg, Germany,

e-mail: kbroeg@meeresforschung.de

Tel.: +49-40-8998 1860, Fax: +49-40-8998 1899

I. Paperna

The Hebrew University of Jerusalem, Faculty of Agriculture,

P.O. Box 12, Rehovot, Israel 76100

\section{A. Diamant}

National Center for Mariculture,

Israel Oceanographic and Limnological Research Ltd.,

P.O. Box 1212, Eilat, Israel 88112

\section{S. Zander · W. Körting}

Tierärztliche Hochschule Hannover,

Fachgebiet Fischkrankheiten und Fischhaltung,

Bünteweg 17, D-30559, Hannover, Germany the liver was tested for its application and reliability in reflecting immunosuppression. Tests were accompanied by chemical analysis of standard organochlorine and heavy metal residues in flounder tissue. A total of 33 parasite species were found. As an indicator species, the mean abundance of Trichodina sp. reflected best the pollution gradient observed with highest infection intensity at the most polluted location. Species diversity was significantly higher in fish caught near the reference site and significantly lower in fish from the polluted Elbe estuary. The use of the heteroxenous/monoxenous species ratio as a marker was not useful at the locations investigated because of the dominance of heteroxenous species at all habitats. Since EROD activity and macrophage aggregate activity were dependent on sex and maturity of female flounder, only male fish were taken into consideration for the integrated evaluation of data. All biochemical and histochemical tests were able to reflect accurately the site-specific differences, as well as an observed pollution event at the end of 1995 as determined by chemical analyses. The correlation analysis revealed a connection not only between the single parasitological and biochemical parameters but also within these groups. The non-specific immune response and Trichodina infection intensity were correlated with all other parameters, leading to the assumption that these may serve as links between the lowest and the highest levels of biological organisation. The simultaneous use of metabolic and parasitological results facilitated the interpretation of the observed variations of the data and the distinction between natural variation and pollution-mediated effects.

Key words Integrated biological effect monitoring . North Sea $\cdot$ Metabolic, pathological and parasitological biomarkers $\cdot$ Platichthys flesus

\section{Introduction}

The development of a reliable and reproducible set of biological tests for environmental risk assessment in coast- 
al marine areas with different zoogeographic habitats was the main objective of the present study. Tests were to include several different levels of biological organisation in each individual fish to determine how far disturbance of the system due to the influence of environmental toxicants had advanced. To obtain information on the ecosystem level, a quantitative operational model for the use of fish parasite communities was developed and tested as a tool for the detection of environmental stress. The potential use of parasites as bioindicators for pollution monitoring is widely and controversially discussed (Poulin 1992; Kennedy 1997; Overstreet 1997), because many natural factors influence prevalence, infection intensity and biodiversity of parasites. The only means to interpret and to evaluate the impact of pollution on parasite burden are long-term studies of comparable habitats and different pollution levels (MacKenzie et al. 1995; Kennedy 1997).

There are numerous ways in which parasites may reflect the host-environmental situation. For example, parasites can react rapidly to deteriorating water quality or immunosuppression of host species. Within days an infection with monoxenous parasites can increase from moderate to severe levels (Skinner 1982). These parasite species can therefore serve as short-term bioindicators, although under certain circumstances they reflect long-term immunosuppressive effects. However, the infection intensity of these species can mark an endpoint at which the host is no longer able to tolerate an environmental stressor.

Other parasite species with heteroxenous life cycles represent indicators for long-term effect monitoring. The gradual reduction of biodiversity may lead to a decrease in intermediate host species and can result in the extinction of one or more parasite species (Overstreet 1997). This applies especially to heteroxenous species valuable for pollution monitoring because the decrease in heteroxenous species diversity, prevalence and infection intensity may reflect a reduction in biodiversity to a wider extent. These species can therefore be used for a long-term biomonitoring, reflecting the processes in a known habitat over a longer time scale.

Within the framework of this study, parasites of the flounder (Platichthys flesus L.) were investigated at four locations in the North Sea. For use in pollution monitoring, the application of three different concepts of parasites as bioindicators was examined: the use of single parasite species as described by several authors (MacKenzie et al. 1995), the parasite species diversity at the different locations (Gelnar et al. 1997) and the concept of heteroxenous/monoxenous species ratio as described by D'Amelio and Gerasi (1997).

Of major importance for the whole project was the supplementation of the parasitological data by wellknown biochemical and histochemical biomarkers at different levels of biological organisation, recommended by the ICES Advisory Committee on the Marine Environment (ACME) (Anonymous 1996) for application in biological effects monitoring programmes. The activity of the CYP1A-dependent monooxygenase ethoxyresorufin
O-deethylase (EROD) was tested as a biomarker of exposure to specific lipophilic compounds like polycyclic aromatic hydrocarbons (PAHs), dioxins and special coplanar polychlorinated biphenyl (PCB) congeners (Goksoyr and Förlin 1992; Boer et al. 1993; Sleiderink et al. 1995). At the subcellular level, the integrity of lysosomal membranes in hepatocytes was taken as an indicator of non-specific acute and chronic toxic effects and its relationship to the histopathological status of liver tissue (Köhler 1991). Liver histopathology may serve as a reliable tool for the observation of the effects caused by pollution (Vethaak and Wester 1996), but its application in routine bioeffect-monitoring programmes is time and cost intensive. In addition to these biomarkers, neutral lipid content in the liver was analysed and used as an indicator for pathologically induced fat accumulation. In the same individual fish, a new method for the measurement of macrophage aggregate activity in the liver was tested for its application and reliability in reflecting immunosuppression in flounder caught at different polluted locations. These tests were accompanied by chemical analysis of standard organochlorine and heavy metal residues in flounder tissue.

With the background of these data, it was intended to compare the parasitological findings with the biochemical and histochemical data from the same individual fish following the line of thought of Khan and Payne (1997). They proposed that by combining different methods of pollution monitoring it might be possible to overcome the problems of interpreting isolated results and to distinguish between natural fluctuation and true pollutionmediated effects.

\section{Materials and methods}

\section{Sampling}

Nine sampling campaigns in the North Sea were conducted from summer 1995 to autumn 1997 (Table 1). During these cruises with the research vessel "Uthörn" of the Biologische Anstalt Helgoland, a total of 742 flounder (Platichthys flesus L.) were caught at three (1995 and 1996) and four stations (April/September 1997). In addition to the three locations sampled in 1995 and 1996 (Elbe estuary, Eider estuary and Tiefe Rinne near Helgoland), in 1997 a station located in front of the East Fresian Island Spiekeroog was sampled. At this location, the salinity is comparable to the waters of Tiefe Rinne and the outer Eider. The stations were determined by their geographical positions. Fishing was conducted with a bottom trawl (opening $1.5 \mathrm{~m}$, mesh width in the cod end $40 \mathrm{~mm}$ stretched mesh). The fishing period (i.e. net on the ground) was limited to $30 \mathrm{~min}$ to keep fishing stress as low as possible. Fish were sorted out immediately and kept in tanks with permanent water flow-through and aeration for up to $6 \mathrm{~h}$ until preparation took place. Only flounder of the size class $18-25 \mathrm{~cm}$ were used for this investigation. Thirty fish per site were collected and prepared for analysis.

\section{Examination procedure}

Most of the procedure took place on board the research vessel. Upon capture, each fish was measured and examined macroscopically for metazoan parasites. All parasites collected, mainly copepods, were stored in $70 \%$ alcohol until further counting and identifica- 
Table 1 Summary of the sampling programme (1995-1997) of flounder ( size class 18-25 $\mathrm{cm})$, including date and site of collection and the number used for biochemical and parasitological analyses

\begin{tabular}{|c|c|c|c|c|}
\hline Campaign/year & Month & Site $^{\mathrm{a}}$ & $\begin{array}{l}\text { No. of fish used } \\
\text { for biochemical } \\
\text { analysis }\end{array}$ & $\begin{array}{l}\text { No of fish used } \\
\text { for parasitological } \\
\text { analysis }\end{array}$ \\
\hline (1) 1995 & June & $\begin{array}{l}1 \\
2 \\
3\end{array}$ & $\begin{array}{l}0 \\
0 \\
0\end{array}$ & $\begin{array}{l}32 \\
29 \\
30\end{array}$ \\
\hline (2) 1995 & September & $\begin{array}{l}1 \\
2 \\
3\end{array}$ & $\begin{array}{r}30 \\
30 \\
9\end{array}$ & $\begin{array}{r}30 \\
30 \\
9\end{array}$ \\
\hline (3) 1996 & January & $\begin{array}{l}1 \\
2 \\
3\end{array}$ & $\begin{array}{l}29 \\
31 \\
30\end{array}$ & $\begin{array}{l}29 \\
31 \\
30\end{array}$ \\
\hline (4) 1996 & April & $\begin{array}{l}1 \\
2 \\
3\end{array}$ & $\begin{array}{l}30 \\
30 \\
14\end{array}$ & $\begin{array}{l}30 \\
30 \\
14\end{array}$ \\
\hline (5) 1996 & July & $\begin{array}{l}1 \\
2 \\
3\end{array}$ & $\begin{array}{r}30 \\
8 \\
30\end{array}$ & $\begin{array}{r}30 \\
9 \\
30\end{array}$ \\
\hline (6) 1996 & October & $\begin{array}{l}1 \\
2 \\
3\end{array}$ & $\begin{array}{l}30 \\
30 \\
30\end{array}$ & $\begin{array}{l}30 \\
30 \\
30\end{array}$ \\
\hline (7) 1997 & January & $\begin{array}{l}2 \\
3\end{array}$ & $\begin{array}{l}0 \\
0\end{array}$ & $\begin{array}{r}18 \\
3\end{array}$ \\
\hline (8) 1997 & April & $\begin{array}{l}1 \\
2 \\
3 \\
4\end{array}$ & $\begin{array}{l}30 \\
28 \\
30 \\
30\end{array}$ & $\begin{array}{l}30 \\
28 \\
30 \\
30\end{array}$ \\
\hline (9) 1997 & September & $\begin{array}{l}1 \\
2 \\
3 \\
4\end{array}$ & $\begin{array}{l}30 \\
30 \\
30 \\
30\end{array}$ & $\begin{array}{l}30 \\
30 \\
30 \\
30\end{array}$ \\
\hline
\end{tabular}

a 1 Elbe; 2 Eider; 3 Helgoland; 4 Spiekeroog

tion. Smears of skin and gills were taken and investigated microscopically for protozons or small metazoan parasites. Meanwhile, the fish was killed by a blow on the head, the peritoneal cavity was opened and the liver colour determined with the help of a colour table (Wahl et al. 1995). Then the liver was carefully removed, without damaging the gall bladder, and the sex of the fish determined. Two samples from the liver were taken and quickly frozen in liquid nitrogen for the determination of EROD activity, macrophage activity and lysosomal stability (see below). Blood smears were taken for examination of protozoan parasites. After processing, the carcass was deep frozen for subsequent analysis of heavy metals and facultative analysis of organochlorine residues in muscle or liver tissue.

All internal organs and the gills were removed and stored in $10 \%$ buffered formaldehyde solution and taken to the laboratory. There, gut and gills were examined for helminths and other parasites under a stereomicroscope before processing two gill arches, pieces of the gut and internal organs for paraffin histology. Sections were stained with Giemsa's technique and examined with a compound microscope for tissue-invading parasites.

\section{Ecological terms}

The following definitions for the ecological terms used in the text are chosen according to the recommendations of Bush et al. (1997) for their use in parasitological studies:

Prevalence is defined as the number of hosts infected with one or more individuals of a particular parasite species divided by the number of hosts examined for that parasite species. It is expressed as percentage.
Mean infection intensity is the total number of parasites of a particular species found in a sample divided by the number of hosts infected by this parasite. The infection intensity can only be determined for countable parasites.

Mean abundance is the total number of individuals of a particular parasite species in a sample of a particular host species divided by the total number of hosts examined for that parasite species. The mean abundance was determined for all countable parasites in this study.

Species diversity is defined in the literature by two components, the number of different parasite species present in a collection and the evenness of distribution of each species. For the comparison of the sampling sites in this study the species diversity is described by the number of different parasite species per host sample at each site. The discussion about the use of diversity indices in the literature, their advantages and disadvantages has led to the conclusion that species indices might be useful for studies of pollution gradients at given locations or long-time biomonitoring of defined regions but not for the characterisation of sampling sites after 2 years of parasite collection (Bush et al. 1997).

All countable parasites, mainly copepods and gut helminths, were determined by their infection intensity. The estimation of the infection intensity by protozoan endoparasites requires the investigation of fresh smears of the organs, but this was impossible because of the dissection procedure on board. Examination was therefore done with preserved material and only the prevalence was noted. For Trichodina sp. the infection intensity was determined by using the paraffin sections and the numbers of animals were divided into three intensity groups, according to the following scale: $0-9$ trichodinids/primary gill lamellae $=1,10-20=2,20-30=3$. In no case were more than 30 trichodinids per gill lamella observed. 
Following the recommendations of Bush et al. (1997) for the quantitative description of parasite communities, not one of the generally used diversity indices was calculated to avoid the alteration of the data. The species diversity and the mean abundance were used to describe and compare the community structure. Species diversity was calculated by counting the number of parasite species present in the collection which included protozoan and metazoan parasites. The mean abundance was estimated by counting the total number of individuals of a particular parasite species at each sampling site divided by the total number of hosts examined.

\section{Statistical analysis}

For the calculation of the H/M index, the mode of reproduction, either monoxenous (from egg or larval stage direct infection of the final host) or heteroxenous (the parasite passes one or more hosts before reaching sexual maturity) as far as it is known from the literature, was used. Due to the missing data about the infection intensity by microparasites (protozoans and myxosporeans), the $\mathrm{H} / \mathrm{M}$ index is based upon the prevalence of the parasites. The $\mathrm{H} / \mathrm{M}$ index was calculated by dividing the number of heteroxenous species by the number of monoxenous parasite species inhabiting the individual fish divided by the total number of fish examined.

Statistical procedures used for parasitological data were the One Way Analysis of Variance, Student's $t$-test for the comparison of sites, Tukey's Studentized Range Test for the comparison of sites and seasons and Pearson's Product Moment Correlation for the comparison of parasites and biochemical data. Differences between groups were considered to be statistically significant at $P<5 \%$.

For the biochemical and histochemical tests the non-parametrical Kruskal-Wallis-ANOVA was applied for the investigation of site-specific differences. Differences between the single sampling sites were considered as significant at $P<5 \%$.

Processing of liver tissue for biochemical and histochemical parameters

\section{Lysosomal stability/macrophage aggregate activity test}

After dissection of the fish, one central part of the liver was quickfrozen in liquid nitrogen and stored at $-70^{\circ} \mathrm{C}$. Serial cryostat sections $(10 \mu \mathrm{m})$ were incubated in $0.1 \mathrm{M}$ citric buffer $(\mathrm{pH} 4.5)$ at $37^{\circ} \mathrm{C}$ for different time periods $(0,2,4,6,8,10,15,20 \ldots 50 \mathrm{~min})$ to determine the lysosomal destabilisation time according to Köhler (1991). Subsequently, labilisation of lysosomal membranes with citric buffer, the histochemical proof of acid phosphatase in macrophage- and liver cell lysosomes, modified after Lojda et al. (1976), was conducted. Sections were incubated for $15 \mathrm{~min}$ in $3.5 \%$ polypep (Sigma), dissolved in $0.1 \mathrm{M}$ citric buffer, $\mathrm{pH} 4.5$, containing $4 \mathrm{mM}$ naphthol-AS-BI-phosphate as substrate for acid phosphatase. After the slides were rinsed in tap water, an azo-coupling reaction was performed in $0.1 \%$ Fast Violet B salt (Sigma) dissolved in $0.1 \mathrm{M}$ phosphate buffer, $\mathrm{pH}$ 7.4. Enzyme activity was assessed as mean absorbance of the formazan-product of acid phosphatase reaction by computer-assisted image analyses, using a Zeiss Axioskop light microscope with monochromatic light $(580 \mathrm{~nm})$ and a 3CCD colour video camera connected to a personal computer, according to Chieco et al. (1994). Lysosomal destabilisation time, the time period of acid labilisation needed to destabilise the membrane, marked by the maximum staining intensity of acid phosphatase in lysosomes, was also assessed by image analysis.

\section{Ethoxyresorufine O-deethylase (EROD) essay}

The preparation of microsomes was performed according to Andersson et al. (1985). The liver tissue $(0.5-0.75 \mathrm{~g})$ was homogeni- sed in four volumes of $0.1 \mathrm{M}$ sodium phosphate buffer $(\mathrm{pH} 7.4)$, including $0.15 \mathrm{M}$ potassium chloride. Homogenisation was carried out using a Potter-Elvehjem glass and a Teflon homogeniser. The homogenates were centrifuged at $10,000 \mathrm{~g}$ for $20 \mathrm{~min}$ and the resulting supernatants were centrifuged at $105,000 \mathrm{~g}$ for $60 \mathrm{~min}$ in a Beckman L2-65B ultracentrifuge. EROD activity was measured as production of resorufin per minute according to Burke and Mayer (1974), using a Shimadzu RF 5001 PC spectrofluorometer with a temperature controlled stirrer cuvette. Total and microsomal protein contents were measured according to Lowry et al. (1951), with an autoanalyser (Technicon, TRAACS 800) using bovine serum albumin as a standard. Whenever determination of EROD activity was not possible within a given time, samples were stored in cryo-tubes in liquid nitrogen. For further analytical details see Krüner et al. (1996).

\section{Analytical chemistry}

Residue analysis was conducted by a commercial laboratory that had undergone an intercalibration exercise (Labor für Rückstandsanalytik Bremen GmbH). From the September 1995 and January 1996 campaigns, ten muscle tissue samples per location were analysed for the content of chlorinated hydrocarbons. For the April 1997 campaign, liver samples were analysed for standard chlorinated hydrocarbons as well. Heavy metals $(\mathrm{Hg}, \mathrm{Pb}, \mathrm{Cd}, \mathrm{Cu})$ in muscle tissue (April 1997 and September 1997, five samples per location) were analysed by a second commercial equally intercalibrated laboratory (Handels- und Umweltschutzlaboratorium Dr. Wiertz, Hamburg). $\Sigma$ PCB was calculated as the sum of PCB $28,52,101,138153$ and 180 .

\section{Results}

\section{Analytical chemistry}

Fish from all North Sea sites were analysed for the content of chlorinated hydrocarbons, and heavy metals. With respect to the residues of chlorinated hydrocarbons, the chosen sites represented a contamination gradient, with highest values measured in fish from the Elbe estuary, followed by the outer Eider individuals, and lowest values in fish from the Tiefe Rinne near Helgoland in 1995 and in the beginning of 1996. The residue data, based upon the fat content, are more meaningful with respect to the chemical burden of the habitat, whereas data on a wet weight basis more adequately reflect the physiological effects of contaminant residues (Wahl et al. 1995). Thus, in Fig. 1, demonstrating the local distribution of selected chlorinated hydrocarbons in flounder tissue values are based on fat. The correlation analyses of residues and biomarkers in contrast were done with values, based on wet weight.

In September 1995 a contamination gradient could be observed with respect to the content of organochlorines in flounder muscle tissue, with highest values in Elbe fish, followed by Eider and Tiefe Rinne animals. Only for two compounds, DDT and DDE, were mean values slightly higher in Eider flounder than in Elbe fish. The amounts of $\Sigma$ PCB, p,p' DDT and dieldrin are shown in Fig. 1. In January 1996 a dramatic increase in PCB and DDT residues in Elbe flounder muscle was observed. Levels of DDT reached 120-fold higher values than 
Fig. 1 Residues of p,p DDT, $\Sigma$ PCB and dieldrin in flounder muscle (September 1995 and January 1996) and in flounder liver (April 1997) from the three, respective four locations in the German Bight. In September 1995 and January 1996, Spiekeroog was not sampled. Values in $\mu \mathrm{g} / \mathrm{kg}$ fat. For key, see Fig. 9
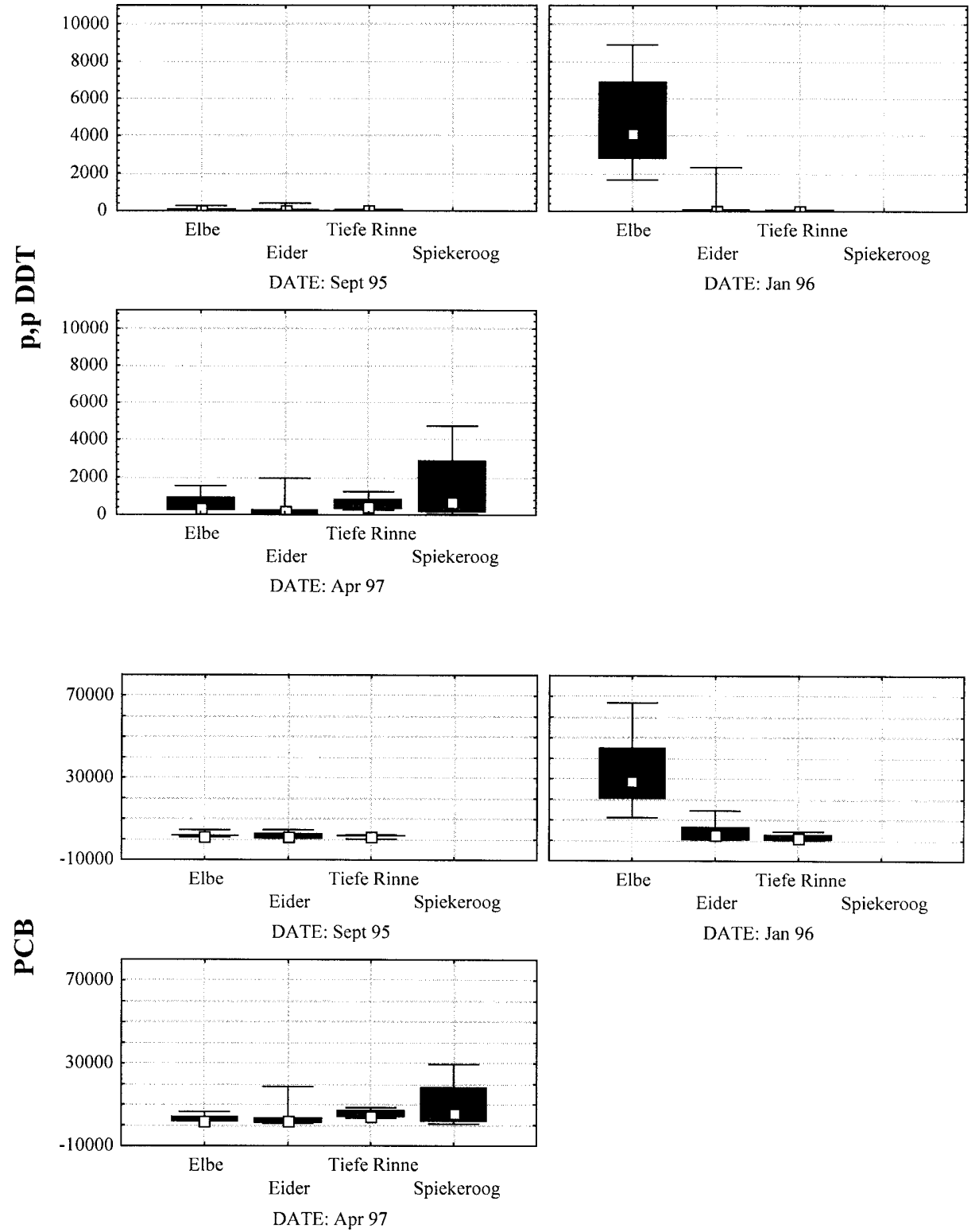

DATE: Jan 96

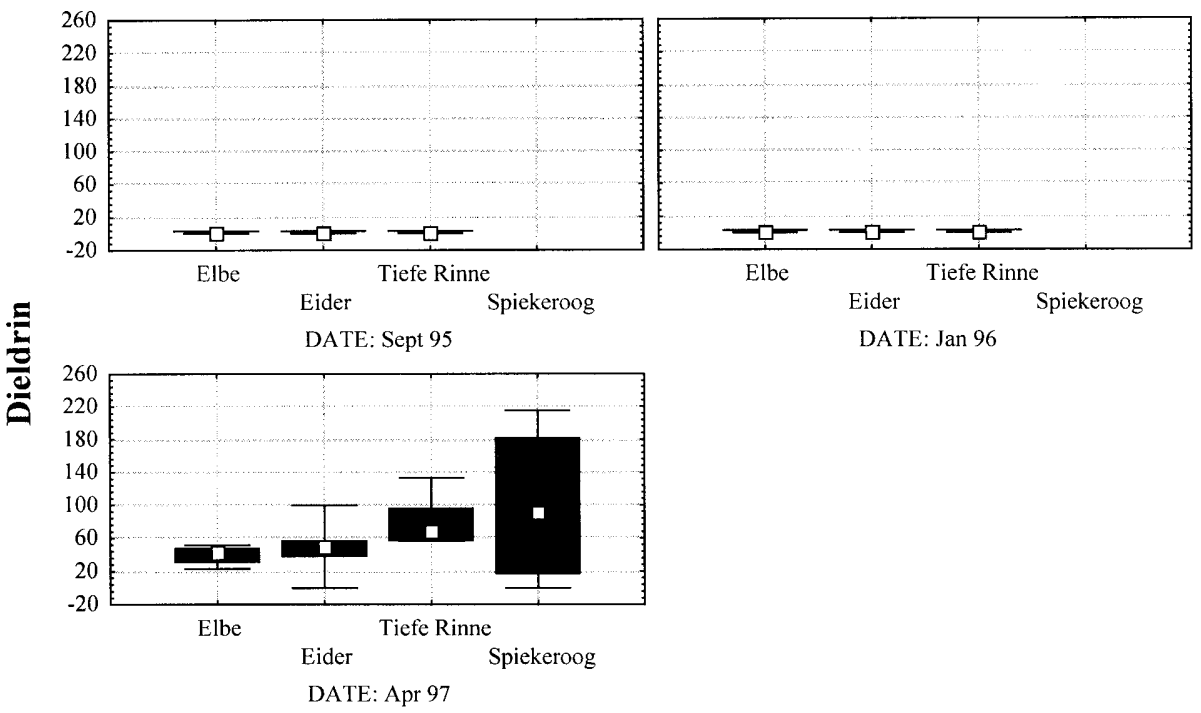

Sampling Locations 


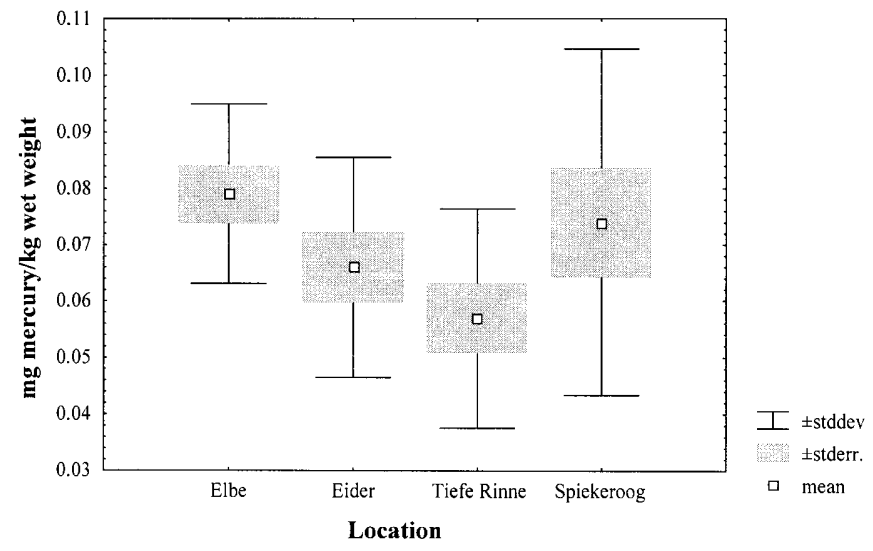

Fig. 2 Mercury in flounder muscle, values in $\mathrm{mg} / \mathrm{kg}$ wet weight, April and September 1997, $n=40$

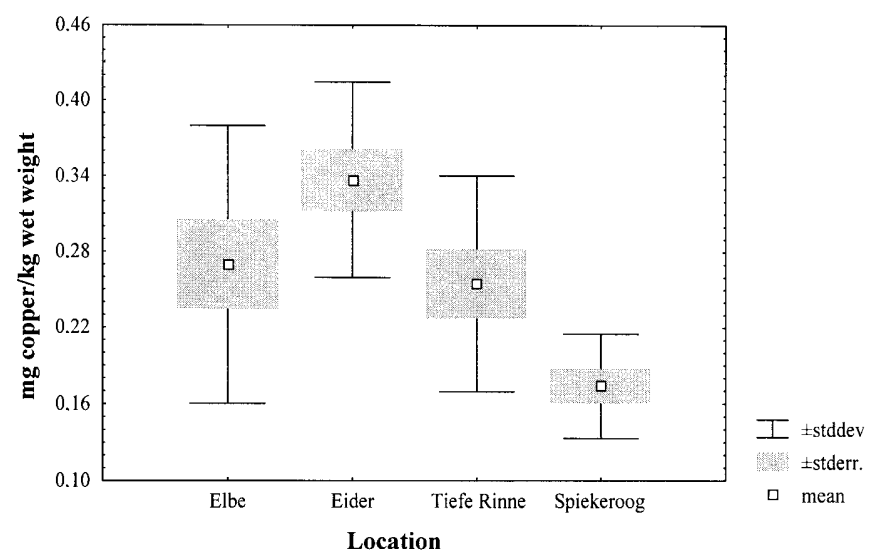

Fig. 3 Copper in flounder muscle, values in $\mathrm{mg} / \mathrm{kg}$ wet weight, April and September 1997, $n=40$

measured in September 1995 (4748, compared to 39.8 $\mu \mathrm{g} / \mathrm{kg}$ fat measured in September). $\Sigma \mathrm{PCB}$ was 16 -fold higher than in September (33824, compared to 1960 $\mu \mathrm{g} / \mathrm{kg}$ fat in September). As shown in Fig. 1, levels of PCB and DDT were also elevated in fish from the Eider estuary. Values of all other tested chlorinated hydrocarbons remained relatively constant and reflected the contamination gradient from the Elbe to Tiefe Rinne.

In the liver of flounder caught in April 1997, residues of PCBs, DDT, DDE, DDD and HCB were highest in animals from Spiekeroog. Here, it should be taken into consideration that only data for four animals from each location were available and the within-site variation was very high. PCB content was lowest in the Elbe estuary, followed by Eider and Tiefe Rinne, with nearly the same mean values of total PCB and highest values in fish from Spiekeroog. HCB, OCS and PCBenz values were still highest in the Elbe estuary (and at the Spiekeroog site), but extremely low in fish from the Eider and Tiefe Rinne. DDT values, which were extremely high in Elbe fish in January 1996, decreased in April 1997 in Elbe animals. In Eider and Tiefe Rinne fish, levels of DDT and its metabolites were elevated in 1997. Dieldrin residues could only be detected when analysing the livers of flounder (Fig. 1). For this compound, a contamination gradient was found, with lowest values in fish from the river Elbe, followed by the Eider and Tiefe Rinne in April 1997. Highest values were measured near the island of Spiekeroog.

The only site-specific differences that could be detected concerning heavy metal residues in flounder muscle were the mercury and the copper content (Figs. 2 and 3). Mercury mean values were highest in the Elbe, followed by Spiekeroog, Eider and Tiefe Rinne, whereas copper was highest in Eider animals, followed by Elbe and Tiefe Rinne fish. Very low values were detected in flounder from Spiekeroog.

Parasite community structure

A total of 742 fish were dissected and 33 parasite species have been identified. For the identification of some rare species of nematodes and trematodes, the help of the International Institute of Parasitology in St. Albans, Hertfordshire, UK, was made use of. Nevertheless, some of the trematodes, nematodes and cestodes, especially the larval forms, were not identifiable. All the unidentified species occurred only once or twice during the course of the examination and were of minor importance for the analysis.

Of the 33 different parasite species identified, 6 were microparasites (protozoa and myxozoa) and 27 species macroparasites. Most of the species were heteroxenous; only 9 monoxenous parasite species were found, mainly copepods and microparasites. Most of the parasites used the flounder as the final host and of the 33 species, 25 were endoparasitic. A considerable number of parasites (17 species) occurred at all four sites; 16 species, mainly helminths, were found at the different locations only sporadically. The taxonomic details and the distribution by sites are given in Tables 2 and 3 .

\section{Microparasites}

Two species of Microspora were found: Glugea stephani cysts in the wall of the gut and an undetermined microsporean parasite regularly infecting the kidney of the flounder. Cysts of the latter parasite were observed usually within the glomeruli, rarely in the parenchymatic tissue, surrounding the glomeruli and tubules. The prevalence of this microsporidian parasite was high: $27 \%$ of the flounder caught in the Eider and Elbe estuary were infected, $28 \%$ of the fish caught near Spiekeroog and 39\% of the fish in the Tiefe Rinne. Prevalences were highest during the autumn campaigns at all sites. Prevalence of G. stephani was low. It occurred twice in fish from the Eider estuary (1995 and 1996), at one occasion in 1996 near Helgoland and only once in 1996 in the Elbe estuary. At each occasion, only one fish out of the whole sample was infected. 
Table 2 Parasites collected from flounder from four sites in the German Bight, including some details on their life cycles

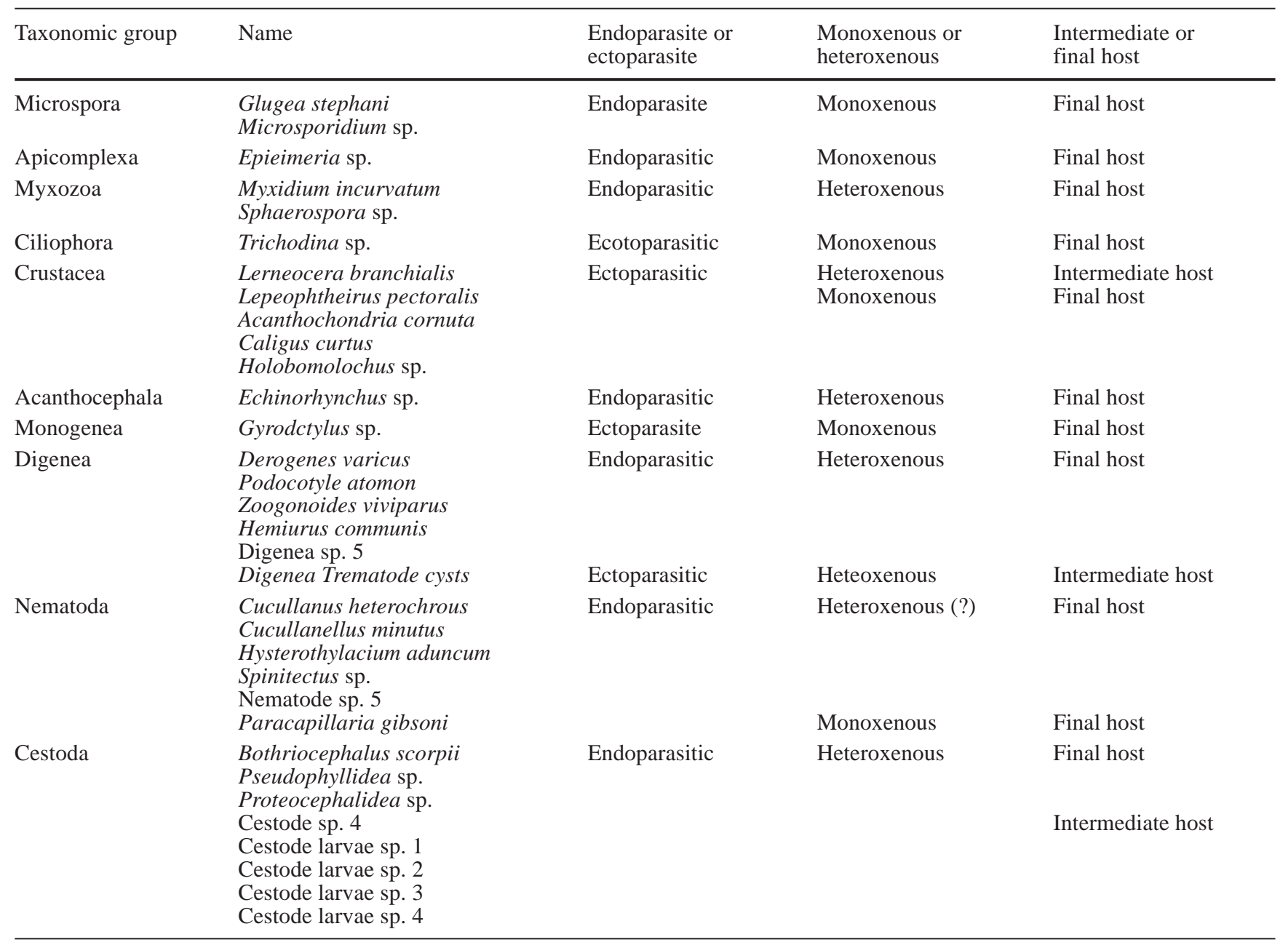

An epieimerian parasite was observed in fresh smears of the midgut epithelium and in histological preparations. No pathological changes were detected, because the infection intensity seemed rather low in all fish investigated. Due to the absence of sporogonic developmental stages, it was not possible to identify this parasite. It occurred regularly at all stations, in $27 \%$ of the flounder caught in the Elbe, in $28 \%$ of the Eider fish, $36 \%$ of the Tiefe Rinne fish and in $33 \%$ of the flounder caught near Spiekeroog, with highest prevalences during spring and summer campaigns.

Spores and other developmental stages of Myxidium incurvatum were found in the gall bladder of $13 \%$ of the flounder caught in the Elbe. No pathological changes caused by the infection were detectable. Fourteen percent of the fish caught in the Eider estuary were infected, $23 \%$ of the fish near Helgoland and $16 \%$ of the fish near Spiekeroog. There seemed to be no seasonal influence on the prevalence of this parasite. An unidentified myxosporean parasite, infecting the kidney tubules of the flounder, was very low in prevalence $(2 \%$ in the Eider, $1 \%$ near Helgoland and 5\% in flounder caught near Spiekeroog). Identification was not possi- ble as no spores were detected. Statistical analysis of the parasite data showed that there was no consistent significant difference between the stations regarding the prevalence of the endoparasitic microparasites. No correlation reflecting the contamination gradient between sites and parasite abundance was found. The only ectoparasitic protozoan parasite found was a ciliophoran species from the genus Trichodina sp. on the gills of the flounder at all sites. The prevalence of this parasite was highest at Elbe station $(76 \%)$ and lowest at Tiefe Rinne near Helgoland, with 30\% of fish infected. The flounder from sites at Eider and Spiekeroog were moderately infected by Trichodina sp., with $47 \%$ and $60 \%$ respectively. Mean abundance of the parasite was highest during the summer months, especially in fish from the Elbe estuary.

In 1996 and 1997, some significant differences regarding mean abundance of Trichodina sp. occurred between the sites. Flounder from the Elbe estuary displayed higher infection intensities than fish from all other sites, while flounder from Helgoland were the least infected $(P<0.01)$. There were no significant differences between fish from Eider and Spiekeroog (Fig. 4). 
Table 3 Prevalence of parasites of flounder sampled at four sites in the German Bight between 1995 and 1997 inclusive. Species with prevalence less than $3 \%$ were excluded

\begin{tabular}{|c|c|c|c|c|}
\hline Parasite & Target organ & Site & Prevalence $(\%)$ & $\begin{array}{l}\text { Mean } \\
\text { abundance } \pm \text { SE }\end{array}$ \\
\hline \multicolumn{5}{|l|}{ Microparasites } \\
\hline Microsporidium sp. & Kidney glomeruli & $\begin{array}{l}\text { Elbe } \\
\text { Eider } \\
\text { Helgoland } \\
\text { Spiekeroog }\end{array}$ & $\begin{array}{l}0.27 \\
0.27 \\
0.39 \\
0.28\end{array}$ & \\
\hline Epieimeria sp. & Gut & $\begin{array}{l}\text { Elbe } \\
\text { Eider } \\
\text { Helgoland } \\
\text { Spiekeroog }\end{array}$ & $\begin{array}{l}0.27 \\
0.28 \\
0.36 \\
0.33\end{array}$ & \\
\hline Myxidium incurvatum & Gall bladder & $\begin{array}{l}\text { Elbe } \\
\text { Eider } \\
\text { Helgoland } \\
\text { Spiekeroog }\end{array}$ & $\begin{array}{l}0.13 \\
0.14 \\
0.23 \\
0.16\end{array}$ & \\
\hline Sphaerospora sp. & Kidney tubules & $\begin{array}{l}\text { Elbe } \\
\text { Eider } \\
\text { Helgoland } \\
\text { Spiekeroog }\end{array}$ & $\begin{array}{l}0 \\
0.02 \\
0.01 \\
0.05\end{array}$ & \\
\hline Trichodina sp. & Gills & $\begin{array}{l}\text { Elbe } \\
\text { Eider } \\
\text { Helgoland } \\
\text { Spiekeroog }\end{array}$ & $\begin{array}{l}0.76 \\
0.47 \\
0.3 \\
0.6\end{array}$ & $\begin{array}{l}0.96 \pm 0.05 \\
0.672 \pm 0.05 \\
0.356 \pm 0.04 \\
0.75 \pm 0.08\end{array}$ \\
\hline \multicolumn{5}{|l|}{ Copepoda } \\
\hline Lerneocera branchialis & Gills & $\begin{array}{l}\text { Elbe } \\
\text { Eider } \\
\text { Helgoland } \\
\text { Spiekeroog }\end{array}$ & $\begin{array}{l}0.82 \\
0.99 \\
0.97 \\
0.95\end{array}$ & $\begin{array}{l}39.784 \pm 6.5 \\
97.779 \pm 10.65 \\
76.728 \pm 7.01 \\
70.867 \pm 12.35\end{array}$ \\
\hline Lepeophtheirus pectoralis & Skin, fins & $\begin{array}{l}\text { Elbe } \\
\text { Eider } \\
\text { Helgoland } \\
\text { Spiekeroog }\end{array}$ & $\begin{array}{l}0.61 \\
0.86 \\
0.87 \\
0.88\end{array}$ & $\begin{array}{c}3.016 \pm 0.5 \\
9.045 \pm 0.54 \\
7.721 \pm 0.65 \\
13.133 \pm 1.4\end{array}$ \\
\hline Acanthochondria cornuta & Gills & $\begin{array}{l}\text { Elbe } \\
\text { Eider } \\
\text { Helgoland } \\
\text { Spiekeroog }\end{array}$ & $\begin{array}{l}0.16 \\
0.77 \\
0.9 \\
0.84\end{array}$ & $\begin{array}{l}0.734 \pm 0.14 \\
6.124 \pm 0.52 \\
7.389 \pm 0.67 \\
8.2 \pm 0.97\end{array}$ \\
\hline Caligus curtus & Skin & $\begin{array}{l}\text { Elbe } \\
\text { Eider } \\
\text { Helgoland } \\
\text { Spiekeroog }\end{array}$ & $\begin{array}{l}0 \\
0.02 \\
0.04 \\
0.14\end{array}$ & $\begin{array}{l}0 \\
0.023 \pm 0.015 \\
0.033 \pm 0.014 \\
0.2 \pm 0.097\end{array}$ \\
\hline Holobomolochus sp. & Nose cavity & $\begin{array}{l}\text { Elbe } \\
\text { Eider } \\
\text { Helgoland } \\
\text { Spiekeroog }\end{array}$ & $\begin{array}{l}0 \\
0.02 \\
0.04 \\
0.07\end{array}$ & $\begin{array}{l}0 \\
0.024 \pm 0.01 \\
0.033 \pm 0.02 \\
0.05 \pm 0.03\end{array}$ \\
\hline \multicolumn{5}{|l|}{ Digenea } \\
\hline Derogenes varicus & Gut & $\begin{array}{l}\text { Elbe } \\
\text { Eider } \\
\text { Helgoland } \\
\text { Spiekeroog }\end{array}$ & $\begin{array}{l}0.01 \\
0.09 \\
0.05 \\
0.09\end{array}$ & $\begin{array}{l}0.071 \pm 0.067 \\
0.198 \pm 0.062 \\
0.07 \pm 0.01 \\
0.1 \pm 0.04\end{array}$ \\
\hline Podocotyle atomon & Gut & $\begin{array}{l}\text { Elbe } \\
\text { Eider } \\
\text { Helgoland } \\
\text { Spiekeroog }\end{array}$ & $\begin{array}{l}0.08 \\
0.36 \\
0.67 \\
0.19\end{array}$ & $\begin{array}{r}2.425 \pm 1.01 \\
8.583 \pm 1.66 \\
34.956 \pm 4.75 \\
1.283 \pm 0.58\end{array}$ \\
\hline Zoogonoides viviparus & Gut & $\begin{array}{l}\text { Elbe } \\
\text { Eider } \\
\text { Helgoland } \\
\text { Spiekeroog }\end{array}$ & $\begin{array}{l}0.01 \\
0.06 \\
0.05 \\
0.07\end{array}$ & $\begin{array}{l}0.008 \pm 0.006 \\
0.275 \pm 0.12 \\
0.086 \pm 0.045 \\
0.2 \pm 0.17\end{array}$ \\
\hline Hemiuris communis & Gut & $\begin{array}{l}\text { Elbe } \\
\text { Eider } \\
\text { Helgoland } \\
\text { Spiekeroog }\end{array}$ & $\begin{array}{l}0.02 \\
0.03 \\
0.01 \\
0\end{array}$ & $\begin{array}{l}0.092 \pm 0.05 \\
0.034 \pm 0.016 \\
0.011 \pm 0.01 \\
0\end{array}$ \\
\hline
\end{tabular}


Table 3 Continued

\begin{tabular}{|c|c|c|c|c|}
\hline Parasite & Target organ & Site & Prevalence $(\%)$ & $\begin{array}{l}\text { Mean } \\
\text { abundance } \pm \text { SE }\end{array}$ \\
\hline Digenean larval cysts & Primary gill arches & $\begin{array}{l}\text { Elbe } \\
\text { Eider } \\
\text { Helgoland } \\
\text { Spiekeroog }\end{array}$ & $\begin{array}{l}0.21 \\
0.36 \\
0.51 \\
0.65\end{array}$ & $\begin{array}{l}5.084 \pm 1.55 \\
18.8 \pm 6.38 \\
15.182 \pm 6.08 \\
21.150 \pm 5.85\end{array}$ \\
\hline \multicolumn{5}{|l|}{ Nematoda } \\
\hline Cucullanus heterochrous & Gut & $\begin{array}{l}\text { Elbe } \\
\text { Eider } \\
\text { Helgoland } \\
\text { Spiekeroog }\end{array}$ & $\begin{array}{l}0.2 \\
0.36 \\
0.57 \\
0.56\end{array}$ & $\begin{array}{l}0.622 \pm 0.19 \\
1.274 \pm 0.18 \\
2.381 \pm 0.27 \\
1.3 \pm 0.31\end{array}$ \\
\hline Cucullanellus minutus & Gut & $\begin{array}{l}\text { Elbe } \\
\text { Eider } \\
\text { Helgoland } \\
\text { Spiekeroog }\end{array}$ & $\begin{array}{l}0.1 \\
0.13 \\
0.06 \\
0.02\end{array}$ & $\begin{array}{l}1.308 \pm 0.72 \\
1.026 \pm 0.22 \\
0.253 \pm 0.18 \\
0.067 \pm 0.052\end{array}$ \\
\hline Hysterothylacium aduncum & Gut & $\begin{array}{l}\text { Elbe } \\
\text { Eider } \\
\text { Helgoland } \\
\text { Spiekeroog }\end{array}$ & $\begin{array}{l}0.06 \\
0.03 \\
0.03 \\
0.14\end{array}$ & $\begin{array}{l}0.066 \pm 0.02 \\
0.059 \pm 0.034 \\
0.06 \pm 0.034 \\
0.233 \pm 0.12\end{array}$ \\
\hline Spinitectus sp. & Gut & $\begin{array}{l}\text { Elbe } \\
\text { Eider } \\
\text { Helgoland } \\
\text { Spiekeroog }\end{array}$ & $\begin{array}{l}0.04 \\
0.01 \\
0 \\
0\end{array}$ & $\begin{array}{l}0.072 \pm 0.03 \\
0.007 \pm 0.006 \\
0 \\
0\end{array}$ \\
\hline Paracapillaria gibsoni & Gut & $\begin{array}{l}\text { Elbe } \\
\text { Eider } \\
\text { Helgoland } \\
\text { Spiekeroog }\end{array}$ & $\begin{array}{l}0.02 \\
0.12 \\
0.16 \\
0.05\end{array}$ & $\begin{array}{l}0.038 \pm 0.03 \\
0.358 \pm 0.12 \\
0.589 \pm 0.13 \\
0.2 \pm 0.17\end{array}$ \\
\hline
\end{tabular}

Fig. 4 Mean abundance of Trichodina sp. during the 3 years of sampling at the three sites. Mean abundance of Trichodina sp. was significantly the lowest at Helgoland station during all years. In 1996 all sites were significantly different $(P<0.01)$ and in 1997 fish from the Elbe estuary were significantly more infected than flounder from all other sites

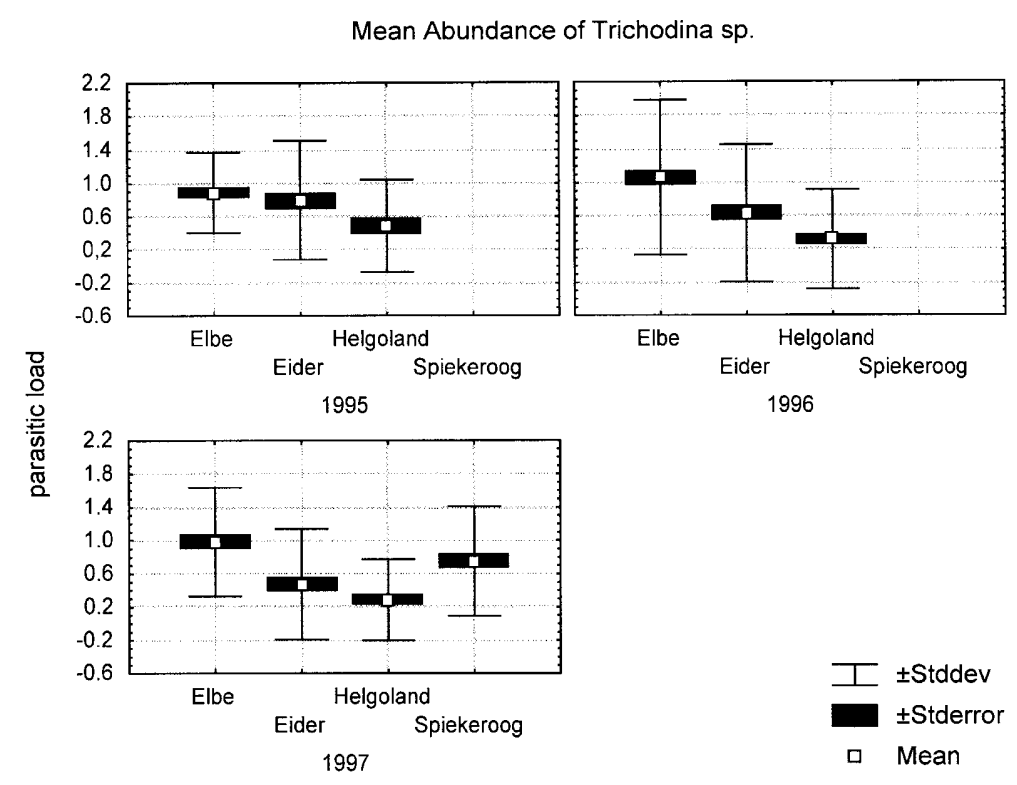

\section{Crustacea}

Lerneocera branchialis, a heteroxenous copepod, occurred in all seasons with high prevalences at all sites. This parasite uses the flounder as an intermediate host. The copepodits are attached to the tip of the lamella of the gills. The final hosts for the adult females are gadoid fish. Prevalence was lowest at the station Elbe during all years $(82 \%)$, while $99 \%$ of the flounder at the Eider estu- ary, $97 \%$ of the flounder caught near Helgoland and 95\% of the fish near Spiekeroog were infected by copepodits. Significant differences in mean abundance were found in each year between the Elbe station and all other sites investigated $(P<0.05)$. The mean abundance increased during winter and spring and decreased during autumn at all stations.

The second species of frequently occurring copepoda at all four sites was Lepeophtheirus pectoralis. This 
Fig. 5 Mean abundance of Acanthochondria cornuta. In 1995, mean abundance of $A$. cornuta was significantly different at all sites investigated $(P<0.01)$. At the Elbe station infection intensity was the lowest during all years $(P<0.01)$

Fig 6 Mean abundance of Podocotyle atomon. Mean abundance of this parasite was highest in flounder caught near Helgoland during all years $(P<0.01)$
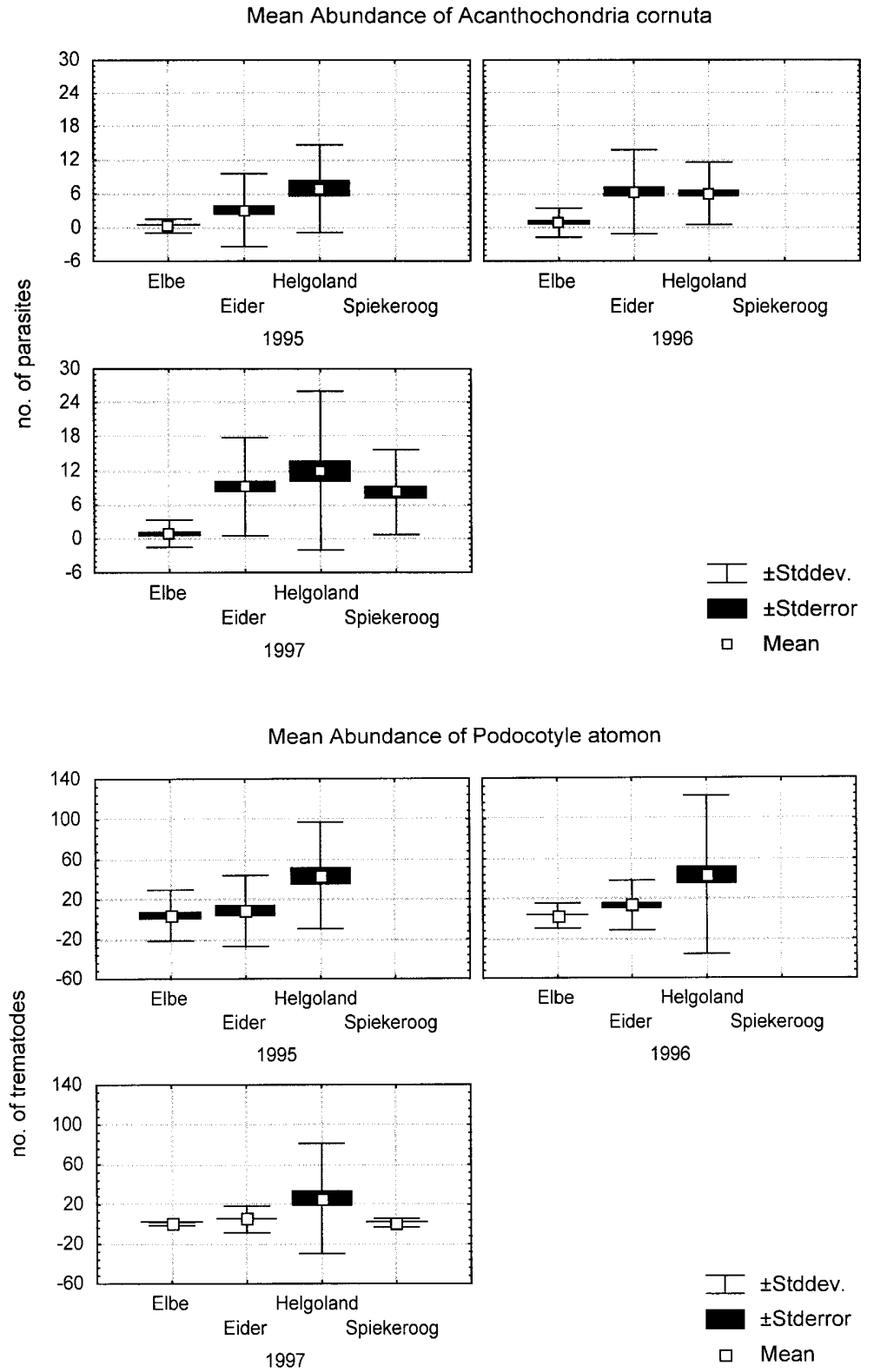

monoxenous copepod parasitises the skin and fins of the flounder. Prevalence was significantly the lowest in the Elbe estuary with $61 \%$ during all years, while $86 \%$ of the flounder in the Eider, $87 \%$ near Helgoland and $88 \%$ near Spiekeroog were infected by this copepod. Mean abundance was lowest at the Elbe station in 1995, 1996 and $1997(P<0.01)$.

A third abundant species of parasitic copepod, Acanthochondria cornuta, also occurred with rather low prevalences on Elbe fish (16\%), while $77 \%$ of the flounder near Eider, 90\% near Helgoland and 84\% near Spiekeroog were infected. The mean abundance of Acanthochondria cornuta was significantly the lowest at the Elbe station in every year $(P<0.01$; Fig. 5$)$.

Finally, there were two very rare species of parasitic copepods. In the nasal cavity of some individuals $\mathrm{Hol}$ obomolochus sp. was detected. Only once in the autumn
1996, 30\% of the flounder caught near Helgoland were infected, but most of the time only one or two out of 30 flounder carried the parasite. The second very rare species was Caligus curtus. This copepod was found occasionally on the skin of single flounder from all stations except in the Elbe estuary.

A consistent result of the prevalence and infection intensity among the sites is that the flounder caught at the Elbe estuary are significantly less infected by copepod parasites than the fish from all other sites. Yet, there was no infection gradient among the sites reflecting significantly the contamination gradient observed. Correlation analysis showed no connection between the prevalence or mean abundance of the parasites and the environmental data of the residue analysis. 
Fig 7 Mean abundance of $\mathrm{Cu}$ cullanus heterochrous. In 1995 there were no differences between the sites. In 1996 only flounder from Helgoland were significantly more infected with $C$. heterochrous than all other sites. In 1997 infection intensity at Elbe and Helgoland varied significantly $(P<0.01)$; flounder from Eider and Spiekeroog displayed comparable infection rates

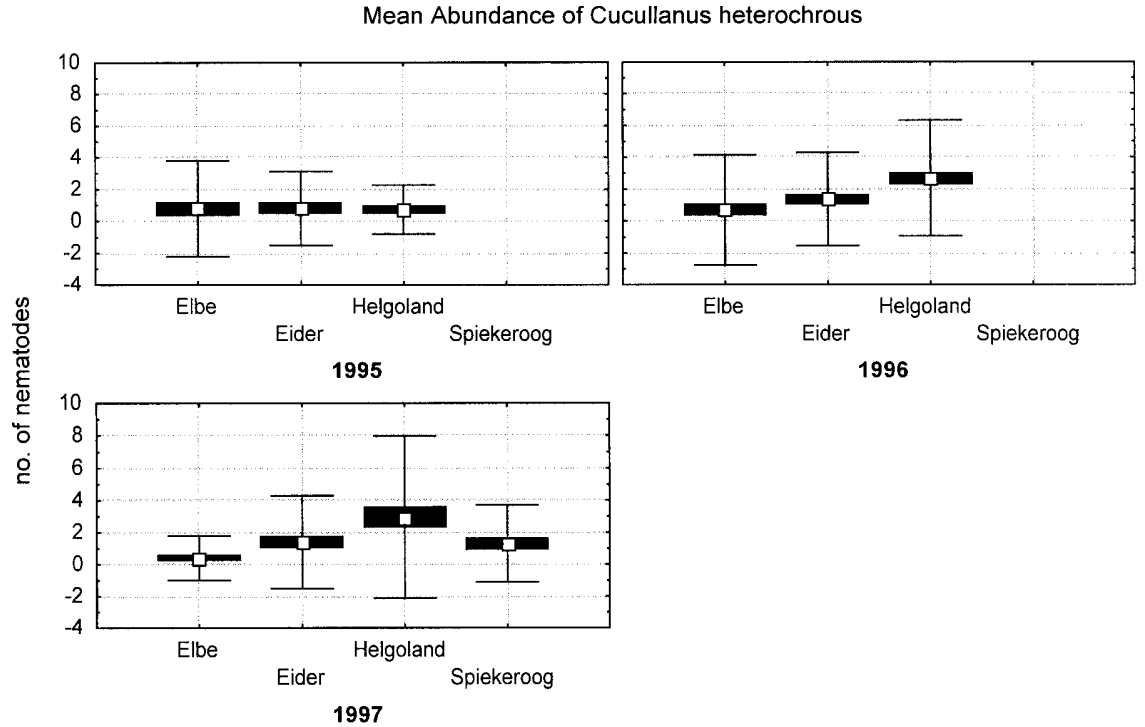

Fig 8 Species diversity at the sampling sites. Despite considerable variation, species diversity was significantly lower at Elbe site than all other stations during the whole period of investigation $(P<0.01)$. In 1997 species diversity varied significantly between Helgoland and the other stations. No differences between Eider and Spiekeroog were detectable
Species diversity of flounder parasites

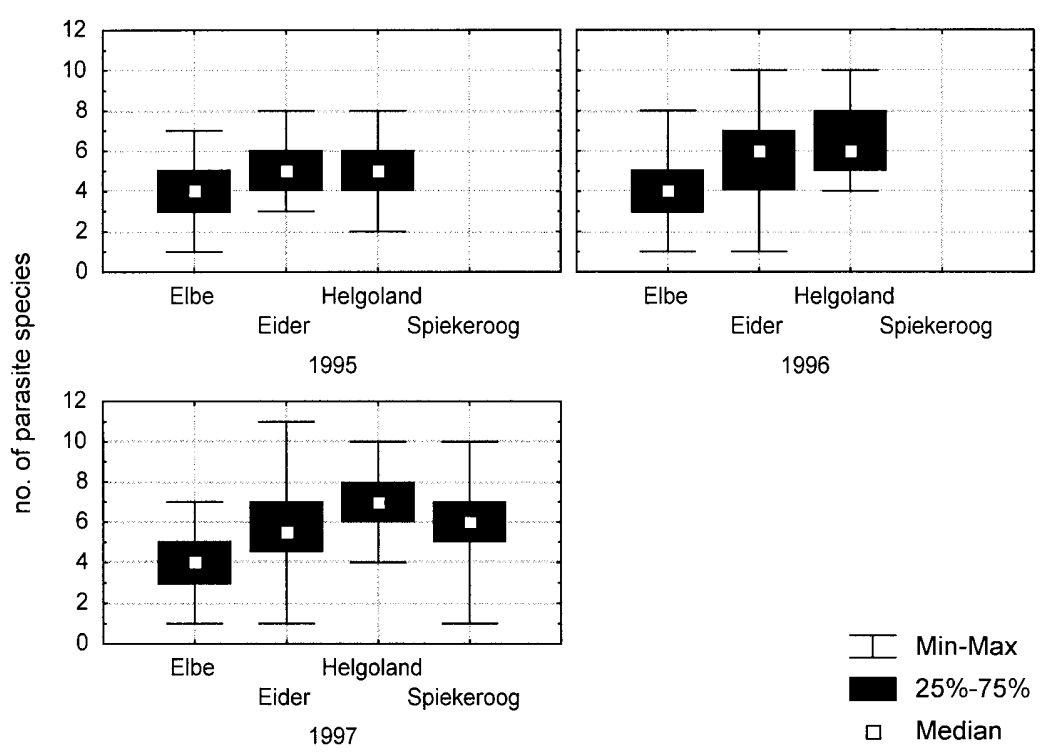

\section{Helminths}

A total of six species of digeneans used flounder as intermediate or final hosts, but only one species, Podocotyle atomon, occurred frequently at all sites. This digenean parasitises the rectal portion of the flounder gut. During all years of sampling, flounder from Helgoland carried significantly higher infections than fish from the other sites $(P<0.01$, Fig. 6). In 1996 mean abundance varied significantly between all stations. Flounder from all sites had digenean larvae encysted in the secondary gill arch, with prevalences from $21 \%$ in the Elbe estuary to up to $65 \%$ of the flounder caught near the island of Spiekeroog. Identification of this parasite was not possible in histological sections. There was no correlation with any of the environmental data and the infection intensity by this digenean.
Only in single flounder caught in the Elbe and Eider estuary a few specimens of Echinorhynchus gadi, Gyrodactylus sp. and a number of young adult cestodes and cestode larvae were found. The metacercaria of an unidentified digenean parasite occurred only twice, once in the Eider estuary and once in the Tiefe Rinne. Further studies are necessary to clarify the origin of these parasites which might be swept into the estuary by the rivers Eider and Elbe.

Cucullanus heterochrous is a nematode that parasitises the midgut of the flounder. In 1995 there was no significant difference between the stations, but in 1996 and 1997 mean abundance at Helgoland was significantly higher than at the other stations $(P<0.05$, Fig. 7). The other four remaining species of nematodes were not frequent enough to serve as bioindicators. 
Fig. 9 Comparison of the H/M index at the different sampling sites. There were no significant differences between the sites and a considerable variation of this parameter at the single stations

Fig. 10 Mean values of the $\mathrm{H} / \mathrm{M}$ index (standard errors were omitted for clarification). Although means of the H/M index were higher at Helgoland station during most of the campaigns, there were no significant differences between sites. No influence of the season was detectable
Comparison of the $\mathrm{H} / \mathrm{M}$-Index over the years

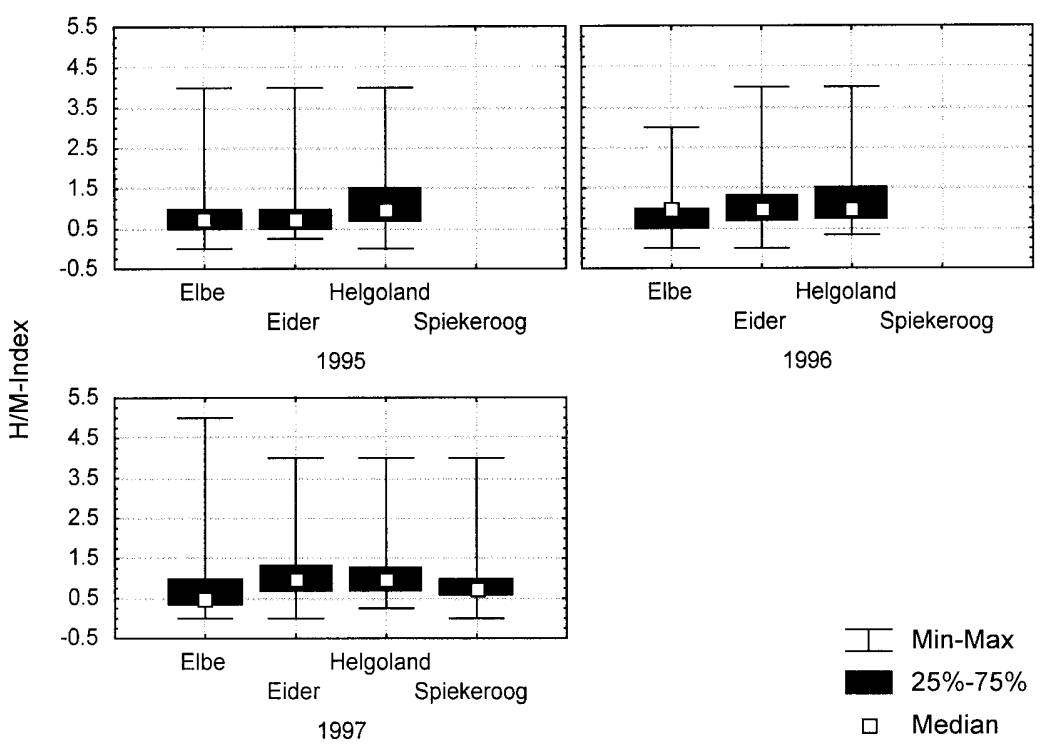

\section{Species diversity}

In 1996 and 1997 there were significant differences between the fish from the Elbe estuary and all other sites investigated regarding the number of different parasite species per individual fish (species diversity) $(P<0.01)$. Flounder caught in the Elbe estuary carried a mean of 3.9 different parasite species during all seasons, flounder caught near Helgoland carried 6.1 and flounder from Eider and Spiekeroog displayed a comparable species diversity of 5.5 and 5.7 respectively. In 1997 the flounder caught near Helgoland carried significantly more parasite species than the fish from all other sites. No such differences were detectable between the Eider and Spiekeroog samples.

A comparison of the mean values of the species diversity over the years as presented in Fig. 8 showed good

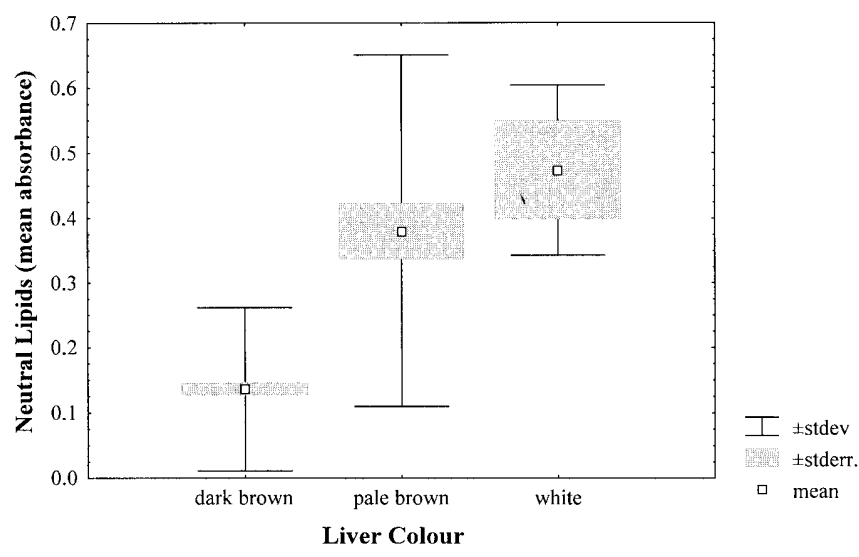

Fig. 11 Liver colour of flounder and pathologically induced accumulation of neutral lipids $(n=223)$. Note relation between white colour and neutral lipids 
Fig. 12 Colour of flounder liver, all campaigns $(*$ significantly different, $P<0.05)$. For key, see Fig. 9

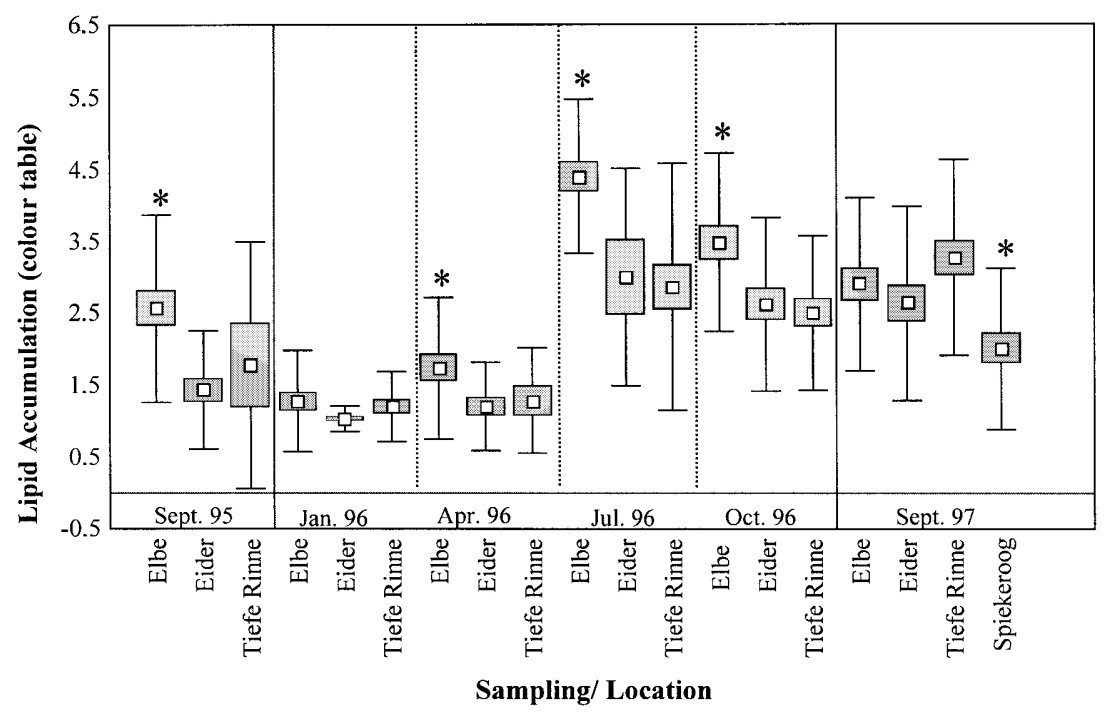

Fig. 13 Lysosomal stability in flounder hepatocytes, all campaigns (* significantly different, $P<0.05)$. For key, see Fig. 9

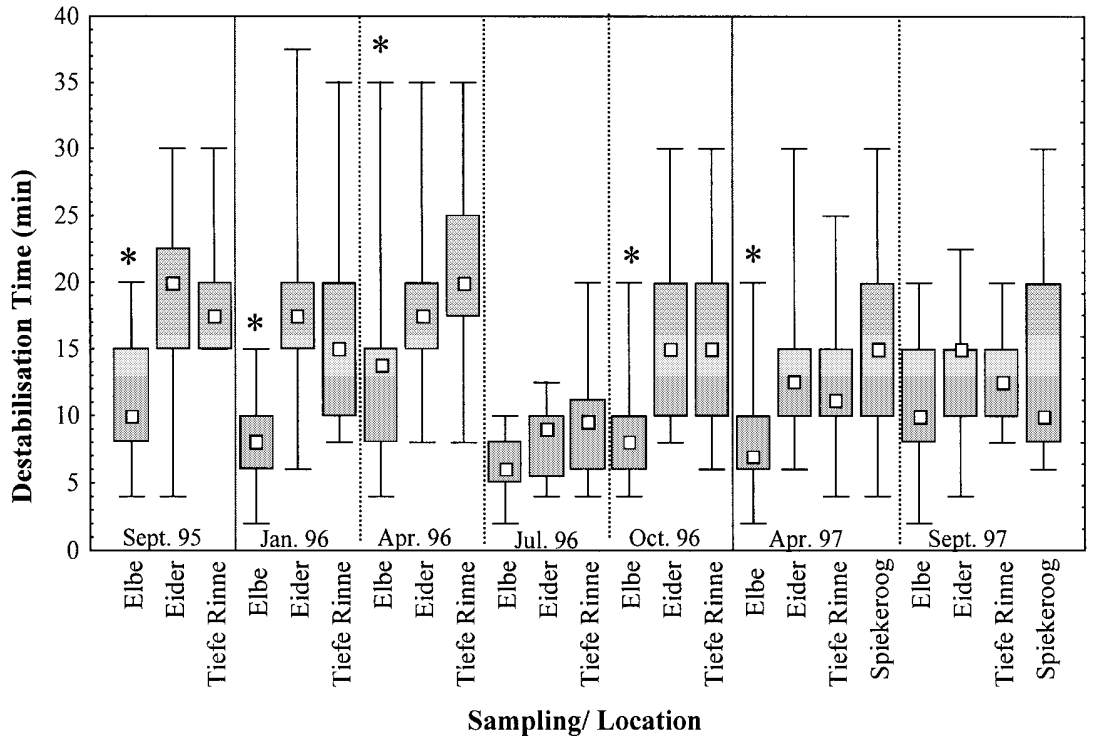

separation of the sampling sites with only two exceptions in summer 1995 and spring 1997. Although there were some fluctuations within this parameter, no seasonal variation was detectable.

\section{Use of heteroxenous/monoxenous species indices (H/M index) in pollution monitoring}

The estimation of the H/M index did not lead to a separation of the locations according to the pollution gradient estimated. For the different years an H/M index of 0.90 and 0.94 was calculated for flounder from the Elbe estuary and Spiekeroog and an index of 1.02 and 1.17 for the fish caught at the Eider estuary and near Helgoland. There were no significant differences between the sites (Figs. 9 and 10). As reported by D'Amelio and Gerasi (1997) different attempts were made to use the H/M index by excluding rare species (less than $5 \%$ prevalence), using only metazoans or by focusing on the 16 most abundant parasite species for the calculation, but it was not possible to achieve a significant separation of the sampling locations.

Biochemical and histochemical tests

\section{Liver colour}

Liver colour was determined with the aid of a colour table, developed within the framework of the project "Fish diseases in the Wadden Sea", supported by the Umweltbundesamt (Wahl et al. 1995). During this project, a correlation between the pathological deposition of neutral lipids in the liver of flounder and the decolorisation of the liver from dark brown to pale brown and white was determined. To test the reliability of the colour table, 223 flounder livers were additionally tested for the content of 
neutral lipids by histochemical investigation. Fig. 11 shows the results of the test. Liver colour was calibrated on a scale from 1 to 5, with the lowest figures given for the darkest colours. Dark brown livers (colour 1) had significantly lower depositions of neutral lipids, compared to pale brown and white livers (colours 3 and 5). Content of neutral lipids and liver colour were positively correlated (Pearson's Product Moment Correlation, $P<0.01)$.

Liver colour was darkest during winter and spring campaigns (Fig. 12), which means that the lowest accumulation of lipid in fish occurred during these campaigns. In winter, the difference in colour within the sites was very small. From the start of feeding in spring, fish caught in the Elbe had significantly elevated neutral lipid accumulation, which means significantly decolorised livers, compared to fish from Eider and Tiefe Rinne (Kruskal-Wallis-ANOVA, $P<0.01$ ), with one exception: in September 1997 Tiefe Rinne fish had the palest livers, the highest degree of pathologically induced lipid accumulation of all sites investigated. Regarding only the autumn campaigns, fish from all tested locations showed higher liver lipid content in 1996 and 1997 than in 1995. In Eider animals, these differences were significant. In Tiefe Rinne fish, lipid accumulation was significantly elevated in September 1997 compared to September 1995.

Liver colour was positively correlated with residues of total PCB and DDT metabolites in fish muscle and liver tissue.

\section{Lysosomal stability}

With lysosomal stability no dependence on the sex of the tested fish could be observed. Yet mature females showed increased lysosomal membrane stability compared to immature individuals and were therefore not taken into account in the evaluation. Significant sitespecific differences were noted at all sampling times except September 1997 (Fig. 13). Elbe fish had significantly lower membrane stability, represented by a low time of acid-labilisation, needed to destabilise the lysosomal membranes than fish from Eider and Tiefe Rinne (Kruskal-Wallis-ANOVA). No significant site-specific effect could be ascertained between Eider and Tiefe
Rinne fish. In September 1997, Elbe fish were not significantly different from animals caught at the other three locations. The differences in membrane stability were not as evident as in the prior sampling campaigns. Lowest values were observed in the Elbe, followed by Tiefe Rinne, Eider and Spiekeroog. The summer campaign of 1996 showed lowest membrane stability at all sites compared with all other samplings. Regarding lysosomal stability in autumn campaigns, 3 years of sampling were compared. Best membrane stability was detected in 1995 at all sites. In 1996, a significant decrease in membrane integrity occurred at all tested locations. Stability levels again decreased in 1997 in fish from Eider and Tiefe Rinne, whereas Elbe fish showed higher membrane stability than in autumn 1996 (Fig. 13).

A negative correlation was ascertained between the residues of DDT and all PCB congeners except PCB 28 and lysosomal membrane stability. Lysosomal stability was also negatively correlated with EROD activity, liver colour and Trichodina infection intensity (Table 4).

\section{EROD activity}

EROD activity was found to be dependent on the state of maturity in female flounder and on the sex of the tested fish. The investigation of 638 flounder in the North Sea showed that EROD activity in female flounder was significantly lower than in male fish ( $t$-test, $P<0.05)$. For this reason, data for male and female flounder were examined separately (Figs. 14a,b).

In male flounder, EROD activity was highest in the Elbe estuary during all campaigns. With the exception of the summer and winter campaign, EROD activity displayed significant site-specific differences at the Elbe station compared to the Eider and Tiefe Rinne. The seasonal within-site variation in this parameter was highest at the Elbe and the Spiekeroog stations. Eider and Tiefe Rinne values were in contrast relatively constant. The spring 1997 campaign showed highest EROD values at all tested locations. A totally different activity pattern could be observed in female flounder. Although fish from the Elbe also displayed significantly elevated EROD activity with one exception, the seasonal withinsite variation was highest at the Tiefe Rinne. In April

Table 4 Correlation between applied parameters in immature male flounder sampled between 1995 and 1997 at four locations in the German Bight $(n=239)$. Pearson's Product Moment Correlation; marked correlations ( $\left.{ }^{*}\right)$ are significant for $P<0.05$

\begin{tabular}{|c|c|c|c|c|c|c|}
\hline & $\begin{array}{l}\text { Trichodina } \\
\text { infection intensity }\end{array}$ & $\begin{array}{l}\text { Parasite } \\
\text { species diversity }\end{array}$ & $\begin{array}{l}\text { Liver } \\
\text { colour }\end{array}$ & $\begin{array}{l}\text { MA } \\
\text { activity }\end{array}$ & $\begin{array}{l}\text { Lysosome } \\
\text { stability }\end{array}$ & $\begin{array}{l}\text { EROD } \\
\text { activity }\end{array}$ \\
\hline $\begin{array}{l}\text { Trichodina } \\
\text { infection intensity }\end{array}$ & 1 & $-0.21^{*}$ & $0.24^{*}$ & $-0.16^{*}$ & $-0.2^{*}$ & $0.14^{*}$ \\
\hline Parasite species diversity & $-0.21 *$ & 1 & 0.06 & $0.14^{*}$ & 0.09 & $-0.26^{*}$ \\
\hline Liver colour & $0.24^{*}$ & 0.06 & 1 & $-0.22^{*}$ & $-0.35^{*}$ & 0.03 \\
\hline MA activity & $-0.16^{*}$ & $0.14^{*}$ & $-0.22^{*}$ & 1 & $0.21^{*}$ & $-0.13^{*}$ \\
\hline Lysosome stability & $-0.2^{*}$ & 0.09 & $-0.35^{*}$ & $0.21^{*}$ & 1 & $-0.21^{*}$ \\
\hline EROD activity & $0.14^{*}$ & $-0.26^{*}$ & 0.03 & $-0.13^{*}$ & $-0.21^{*}$ & 1 \\
\hline
\end{tabular}


Fig. 14 EROD activity in a male and $\mathbf{b}$ female flounder, all campaigns (* significantly different, $P<0.05)$. For key, see Fig. 9

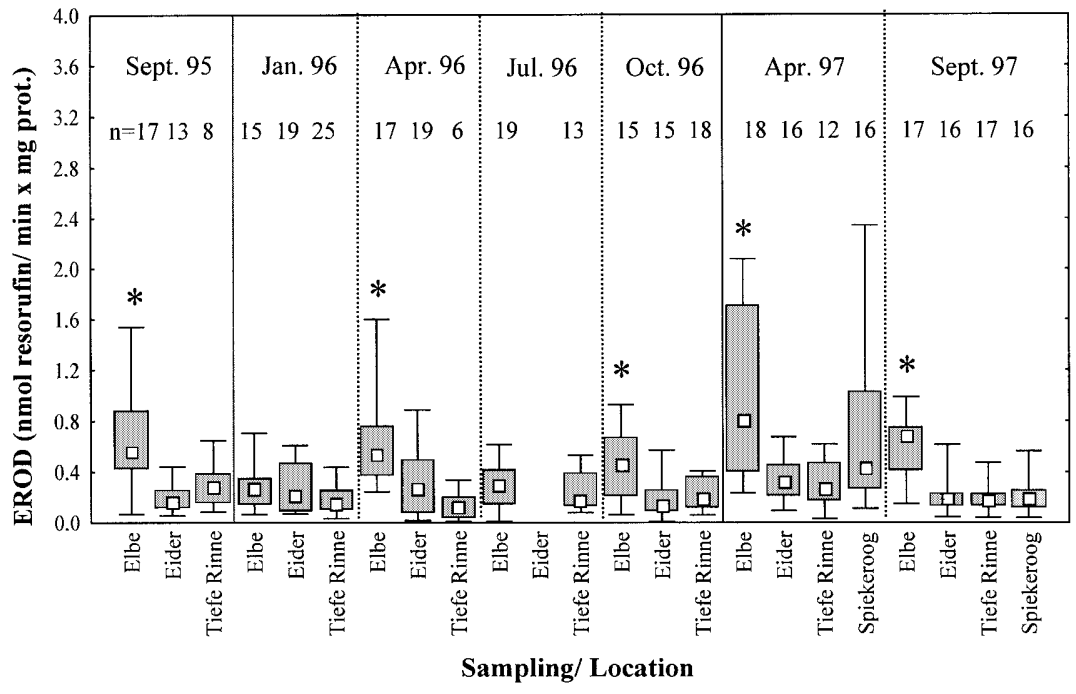

b

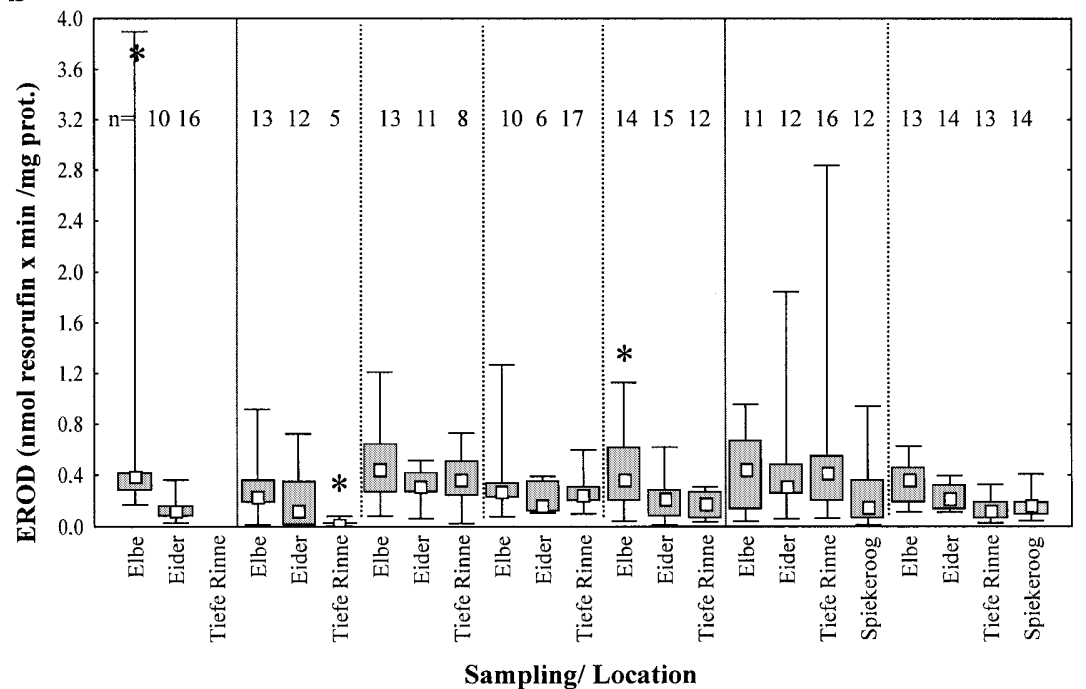

1997 EROD activity in female flounder was highest in the Tiefe Rinne, followed by the Eider and Elbe. The September sampling in 1997 displayed the "normal" distribution pattern of EROD activity again: in male as well as in female flounder highest EROD values occurred in the Elbe, lower activity in the Eider, Tiefe Rinne and Spiekeroog. Looking at the differences between the two spring campaigns (1996 and 1997), an elevated EROD activity in male and female flounder could be observed in 1997 compared to 1996 at all sites, except in Elbe female flounder.

\section{Macrophage aggregate (MA) activity test}

For MA activity, a dependence on maturity and sex of the tested fish could be observed. Mature female individuals showed significantly lower MA activity than immature animals ( $t$-test, $P<0.05)$. Outside the spawn- ing season, female flounder displayed significantly higher MA activity than males. Male and female flounder were therefore evaluated separately. Figure 15a,b shows the different site-specific effects on male and female fish during the whole research programme. In male flounder no interference between maturity and activity of liver macrophage aggregates was observed. On three occasions, male individuals from the Elbe estuary had significantly lower MA activity compared to the Eider, Tiefe Rinne and Spiekeroog. Significant site-specific differences in MA activity in male animals could be detected in spring 1996 and 1997 and in October 1996 (Kruskal-Wallis-ANOVA). Lowest MA activity of all campaigns was found in September 1997 at all locations. In April 1997 MA activity in animals from the Tiefe Rinne was not significantly different from fish caught at the Elbe estuary. This result corresponds to the decrease in all other parameters in 1997 in fish from Tiefe Rinne. 
Fig. 15 Macrophage aggregate activity in liver of $\mathbf{a}$ male and $\mathbf{b}$ female flounder, all campaigns (* significantly different, $P<0.05)$. For key, see Fig. 9 a

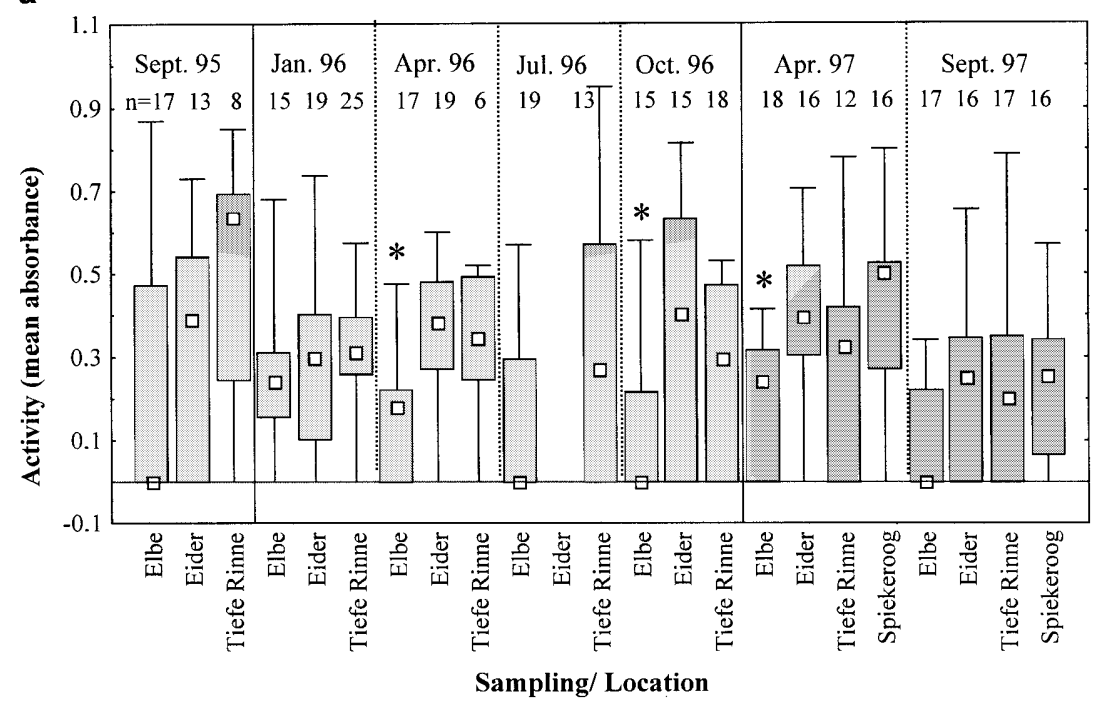

b

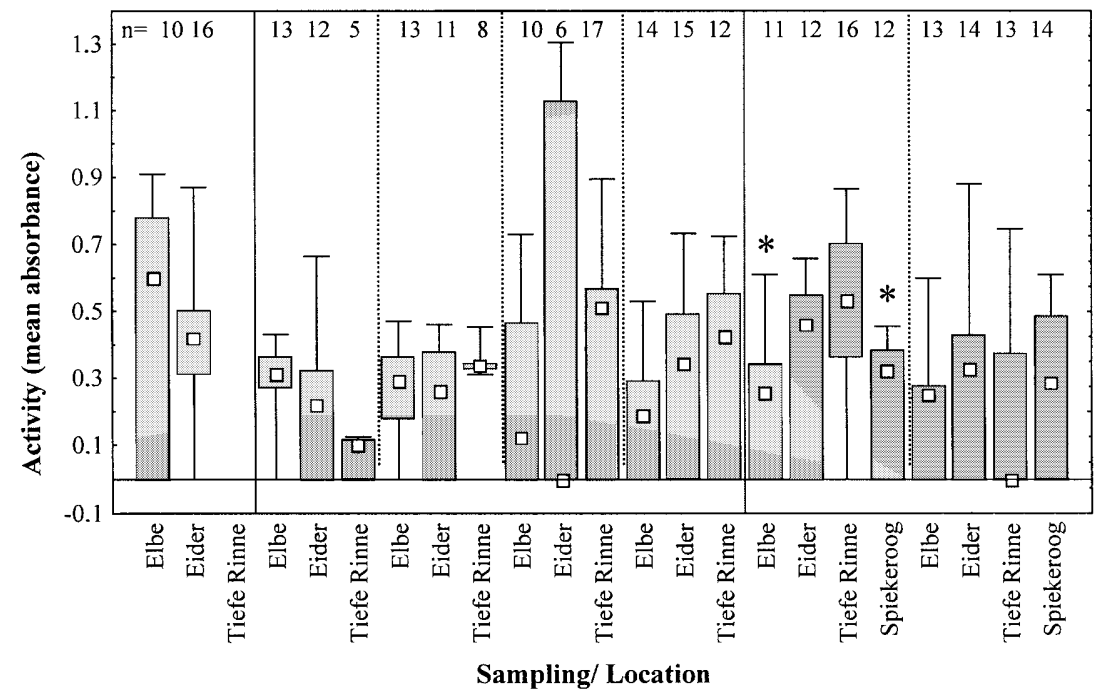

In female flounder, site-specific differences in MA activity were less clear than in male individuals. Significant differences were only observed in April 1997, with significantly lower activity in the Elbe estuary and at Spiekeroog compared to Eider and Tiefe Rinne. In September 1995 and January 1996, female flounder from the Elbe showed higher mean activity values than fish caught in the Eider and Tiefe Rinne. The dependence of MA activity on maturity in female flounder is reflected by low MA activity values during the reproductive period in winter.

A correlation between single chlorinated hydrocarbons and the non-specific immune response could be detected, examining male and female flounder separately. These correlations were only found with residues analysed in the liver of fish and not with residues measured in muscle tissue. In male flounder, a significant negative correlation between dieldrin and MA activity could be ascertained (Pearson's Product Moment Correlation, $P<0.05$; Fig. 16). All other chlorinated hydrocarbons tended towards a negative correlation with the MA activity. In contrast, in female flounder PCB 28 was positively correlated with MA activity (Pearson's Product Moment Correlation, $P<0.05$; Fig. 17). It has to be taken into consideration that the $n$ value for this correlation was very low (female $n=11$, male $n=7$ ). Nevertheless, the different effects on female and male individuals were also reflected in the results obtained during individual campaigns. MA activity in female flounder was frequently higher in the Elbe estuary than in Eider and Tiefe Rinne, especially in September 1995 and January 1996, whereas in male fish immunosuppression was observed in animals caught in the Elbe compared to Eider and Tiefe Rinne samples.

\section{Correlation analysis of parasitological and biochemical data}

The results of the correlation analysis (Pearson's Product Moment Correlation) of the biochemical and parasitolog- 


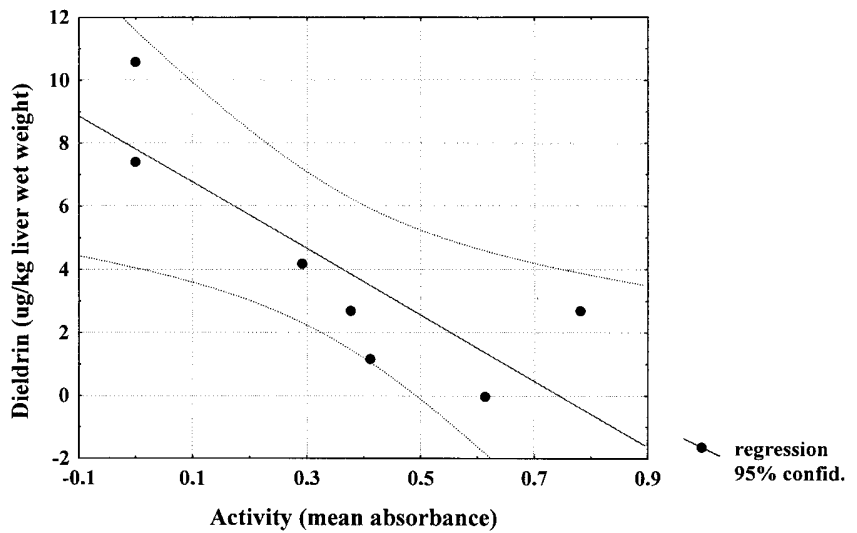

Fig 16 Macrophage aggregate activity versus dieldrin residues in male flounder liver, $n=7$, correlation $r=-0.8247$

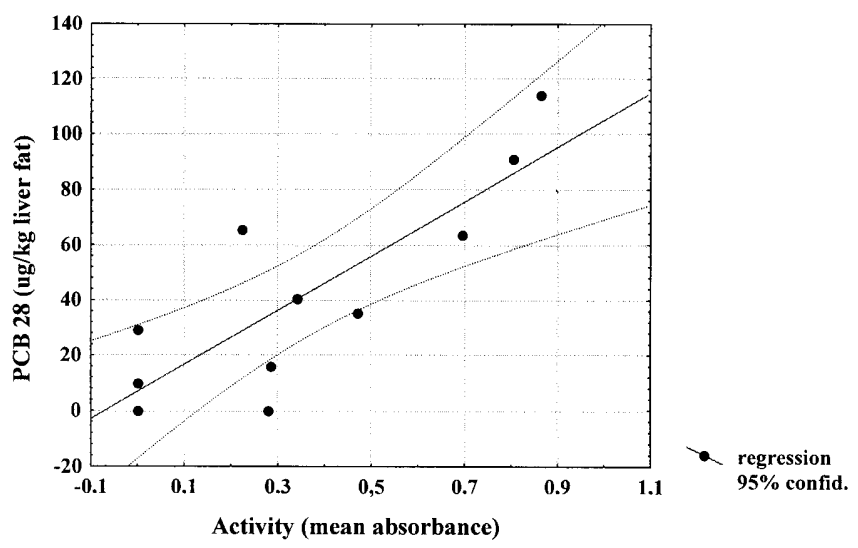

Fig 17 Macrophage aggregate activity versus PCB 28 residues in female flounder liver, $n=11$, correlation $r=0.82744$.

ical data for each campaign did not reveal a constant pattern of correlation. The results were never contradictory, i.e. that the parameters correlated positively at one time and negatively at another. However, there was no consistent correlation between two parameters during the whole sampling period.

The species diversity, the parameter that reflected the characteristics of the habitats best, correlated positively with the lysosomal stability in January, April and October 1996 as well as in April 1997. In animals with a high parasite species diversity, lysosomal membrane stability was high as well. With EROD activity the relationship was different. Diversity correlated negatively with the EROD activity in January 1996 and October 1997. Fish with low parasite species diversity displayed elevated EROD activity.

To eliminate the interfering factors such as sex and maturity on single parameters, or EROD and MA activity, a correlation analysis of the applied parasitological and metabolic parameters was conducted on adult immature male flounder. As shown in Table 4 there are not only correlations between the single parasitological parameters on the one hand, and the biochemical and histochemical parameters, on the other, but also marked links within the two groups.

\section{Discussion}

Environmental monitoring is viewed as an integral, and often the most critical, component of coastal resource management as it provides information that might be useful not only for the protection and rehabilitation of the natural environment and its valued resources but also for evaluation of public policy mandates designed to abate the degradation of coastal environmental quality (National Academy of Sciences 1990). For the assessment of environmental quality, biomarkers are needed for use as a measure of health and fitness (Stegeman et al. 1992, in den Besten 1998). Reflecting the hierarchical and concentric organisation of biological systems, effects of chemical contaminants may occur at all levels of biological organisation, that is from cells to ecosystems. Effects on biological populations, communities and ecosystems, either direct or indirect through habitat degradation, seem to have more relevance in terms of environmental management and protection of resources than effects measured at molecular or cellular level of biological organisation (Wolfe 1992), but these are sometimes difficult to ascertain. As a prerequisite for the use of parasites and parasite community data as bioindicators for environmental quality assessment, long-term studies of parasite communities at comparable localities with known pollution levels are desirable to distinguish between natural fluctuation and pollution-mediated effects (Kennedy 1997; Lotz 1997). A sufficiently large sample size of comparable size classes of fish and respective replicates is also necessary. Unusual natural phenomena, life span of parasites and if possible information about the susceptibility of adult parasites, their developmental stages and intermediate hosts to pollutants have to be taken into consideration when interpreting the results.

The aim of this study is the development of an integrated set of biomarkers to determine the health status of individuals and populations, accompanied by chemical residue analysis. Here, we assess the value of the three types of data collected in terms of their usefulness for environmental quality assessment. Thus, we are dealing with analytical chemistry, the parasitological, biochemical and histochemical parameters.

\section{Analytical chemistry}

The analytical determination of organochlorines in animal tissue in addition to biological tests is noteworthy because of their diversity and persistence in the environment and their demonstrated harmful effects on the biota. Nearly 15,000 chlorine-containing compounds are currently produced for use in pesticides, herbicides, fungicides, pharmaceuticals, disinfectants and many consumer products (Hileman 1993). Compared to the data obtained in other research projects on "Fish diseases in the Wadden Sea" and "Fish diseases in the North Sea" from 1988 to 1992 (Wahl et al. 1995; v. Landwüst et al. 1996), in which the Elbe and the Eider stations have also 
been sampled, a decrease in all chlorinated hydrocarbons could be found from 1989 to September 1995 in muscle of Elbe flounder. DDT, for example, dropped from $243 \mu \mathrm{g} / \mathrm{kg}$ fat in 1989 to $40 \mu \mathrm{g} / \mathrm{kg}$ fat in September 1995, PCB 153 from 2346 to $411.5 \mu \mathrm{g} / \mathrm{kg}$ fat and HCB from 1047 to $221.5 \mu \mathrm{g} / \mathrm{kg}$ fat. For all organochlorines analysed except DDT, residue values decreased in Eider flounder during these 6 years of investigation. A definitely new discharge of contaminants, reflected in the high values of DDT and PCBs measured in Elbe fish in January 1996, changed the picture of improvement of the contaminant situation dramatically. In January 1996, residue values of DDT in flounder muscle were 20-fold higher than in 1989 and PCB 153 was more than threefold higher than in 1989 (present study). The other analysed organochlorines remained at the relatively low levels for Elbe fish, measured in September 1995. Thus, findings indicate that the pollution event was restricted to PCBs and DDT. In 1997 these compounds spread further to the reference areas in the Eider and Tiefe Rinne near Helgoland. Fish from the Tiefe Rinne showed elevated values of DDT and PCBs in relation to the Elbe animals in spring 1997. This is also reflected by sediment analyses (v. Westernhagen, unpublished data). Compared to data obtained in 1992 (v. Landwüst et al. 1996), in flounder liver from the Elbe and Eider locations PCB 153 levels were nearly the same in April 1997 compared to 1992 in Elbe fish, but elevated in flounder from the Eider $(1529 \mu \mathrm{g} / \mathrm{kg}$ fat in $1992,2039 \mu \mathrm{g} / \mathrm{kg}$ fat in 1997). Looking at DDT residues, values measured in 1997 in the liver of Eider flounder were 20-fold higher than measured in 1989 in fish from the same location $(506 \mu \mathrm{g} / \mathrm{kg}$ fat in $1997,26 \mu \mathrm{g} / \mathrm{kg}$ fat in 1989).

For residues of mercury in marine and freshwater fish, the natural background level for most species is in the region of $0.05-0.1 \mathrm{mg} / \mathrm{kg}$ wet weight (ICES 1984; Kruse and Krüger 1984). In the present study, the mean values in flounder from all tested locations were within this range. The finding that there were no correlations between the applied biomarkers and the residues of heavy metals also indicates that the present amounts of heavy metals do not pose a risk to individual health.

The results of the residue analyses indicate that every site and season sampled in the North Sea has its own pollution pattern. No location is "unpolluted". The mixture of chemicals varies not only between the sites and sampling campaigns, but also between specimens from the same location.

\section{Parasitological parameters}

\section{Indicator species}

In order to use single parasite species as bioindicators it is important that these species occur regularly at the locations investigated. They should be easy to locate, identify and should be sensitive to environmental changes before a majority of less sensitive organisms are serious- ly affected. The species life cycles should be known and laboratory studies on their response to pollutants determined. However, these desirable prerequisites for single parasites as bioindicators of pollution are hardly ever fulfilled, certainly not with regard to marine parasites.

Recent studies under field conditions have shown that trichodinids can serve as sensitive short-term bioindicators of environmental stress, especially for eutrophication (Mackenzie et al. 1995; Yeomans et al. 1997), oil pollution (Khan 1987, 1990, 1994), industrial effluents (Overstreet and Howse 1977) and thermal effluents (Nilson 1995). Enhanced pollution leads to an increase in the mucosecretion by gill tissue, which serves as a perfect habitat for Trichodina sp. At the sites investigated in the North Sea, the mean abundance of Trichodina sp. was significantly higher in the Elbe estuary than at all other sites. Flounder from Helgoland, the least polluted site, were less infected by Trichodina sp. during all seasons. This infection pattern reflected the pollution gradient observed between the sites. The abundance of Trichodina sp. increased with increasing pollution. There were only minor seasonal variations within the data and this did not mask the differences between sites. Trichodinids do probably react as well to a lowered immune response of the fish host as to an increase in organic matter in the water. The infection intensity by single species of Trichodina can therefore be used as a true bioindicator.

There have been some major differences between the sites regarding infection patterns with different parasite groups. Fish from the Elbe estuary were always less infected by copepods than flounder caught near Helgoland, while flounder from Helgoland were always more infected by helminth parasites. To some extent these differences may be site specific and not pollution dependent. Only long-term observations of the population dynamics in conjunction with information on residue analysis of fish muscle and sediment may reveal a potential relationship between the environment and parasite populations. In this respect, it is of interest to note that gastrointestinal helminths are negatively affected by a number of aromatic and heterocyclic compounds (Khan and Kiceniuk 1983) possibly through physiological changes in the host, which made the gut inhabitable for helminths (Dey et al. 1983), resulting in a significantly lowered species diversity and infection intensity of helminth parasites at polluted habitats. Other pollutants have an immunosuppressive effect which may lead to an enhanced susceptibility to specific helminth infections (Poulin 1992). Although there are some indications of the usefulness of the infection intensity of several parasitic groups for environmental quality assessment, at this point of the study the infection intensity by Copepoda, Nematoda and Digenea should be considered as preliminary. Although these species would be very useful as bioindicators, because they are abundant, easy to detect, count and identify, little is known about their biology and reaction to pollutants. A further comparison of environmental data, pollution analysis and parasitological data will provide more information on the mechanisms behind the observed differences in infection intensity. 
Fig. 18 Comparison of mean values of species diversity among sampling stations (standard errors are omitted for clarification). With the exception of sampling campaigns in summer 1995 and spring 1997 there was a good separation of all sites on the basis of species diversity. Flounder from Eider and Spiekeroog showed very similar values

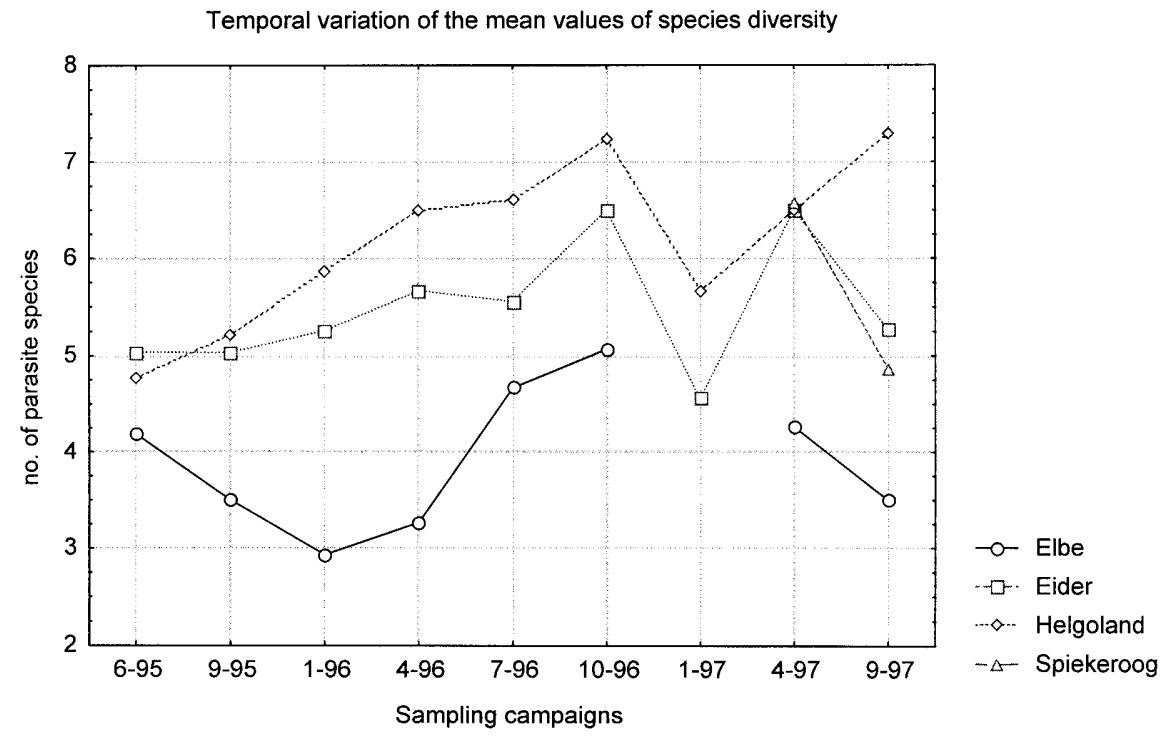

Fig. 19 Distribution of species diversity (number of parasite species/host) within fish samples. The distribution pattern of species diversity at sampling sites in 1996 and 1997 illustrates differences in numbers of flounder infected by numerous parasite species

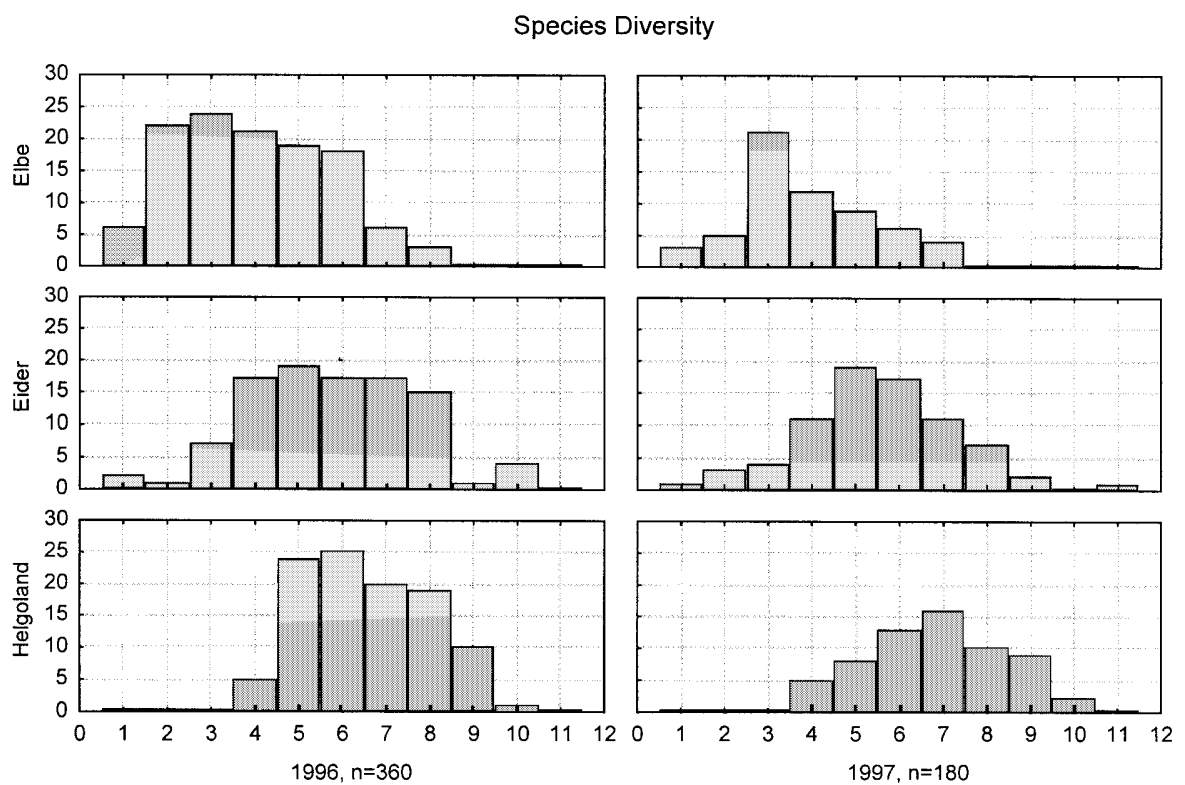

\section{Species diversity}

Following the recommendations of Bush et al. (1997), no diversity indices have been calculated since indices may alter the structure of a parasite assemblage and thus mask real distribution patterns. More information is provided by the description of parasite prevalence, mean abundance and species diversity. Species indices include data on species diversity and abundance; therefore the application is limited to countable metazoan parasites. This restriction excludes a group of parasites, the protozoans, from the analysis before knowing its ecological importance (D'Amelio and Gerasi 1997).

The use of parasite species diversity as a biomarker in pollution monitoring is a way of summarising pollutioninduced effects on a sensitive habitat (the fish) over time. Although parasites can react very inconsistently, differ- ent taxonomic groups included in calculations of species richness or diversity may actually react in the opposite direction (Lafferty 1997); the survey of the species diversity offers a detailed assessment of the environmental changes at community level. Studies of parasite populations of Pseudopleuronectes americanus and Platichthys flesus over decades have shown that species diversity decreases as a consequence of the deteriorating environment owing to urban and industrial pollution (Burn 1980; Sulgostowska 1988).

In the present study as well, species diversity clearly reflected the pollution gradient between the sites. In 1996 differences between all sites were significant. Although in 1997 there was no difference between Eider and Spiekeroog, differences between Elbe and Helgoland and the other two sites were significant, underlining the usefulness of this parameter as a biomarker (Figs. 18 and 19). 


\section{H/M index}

In this study the use of the H/M index for classification of the different habitats did not materialise as hypothesised. The great number of abundant heteroxenous species made it impossible to characterise the stations with their different pollution levels by this index. D'Amelio and Gerasi (1997) solved the problem of lacking sensitivity of the $\mathrm{H} / \mathrm{M}$ index by excluding the less abundant species from the calculation, mainly heteroxenous species.

One further limitation of using the H/M index is the sparse knowledge of the life cycles of the parasites of the North Sea fish. Although described as heteroxenous by several authors (Janiszewska 1938; MacKenzie and Gibson 1970; Möller 1974), laboratory studies indicate that a direct infection of the final host by the secondary larvae of the nematode species Cucullanus heterochrous and $C$. minutus might be possible (Gibson 1972). Some of the protozoan life cycles are unknown. These uncertainties make the separation of the parasites into monoxenous and heteroxenous species sometimes doubtful. However, the H/M index may serve as a very helpful tool in long-term biomonitoring of habitats. Yet, in conjunction with the species diversity, the H/M index characterises the species composition at a given location and the change of the index may serve as a tool for the detection of a change in the overall species diversity. Under natural conditions there will always be some uncertainty if the phenomena observed are really a result of pollution or a natural phenomenon. Some interesting patterns especially in freshwater environments have been observed and it is a challenging task to transfer these concepts to the even more complex marine habitat (Poulin 1992).

Especially in coastal habitats, a mixture of pollutants interact at all trophic levels. This is one of the crucial points in comparing the results of laboratory investigations with field studies where a wide variety of natural factors interact with anthropogenic impacts in an unpredictable way. Thus, laboratory and field studies are necessary for a better understanding of the mechanisms that lead to different infection patterns (Lafferty 1997). The prospective task of a long-term biomonitoring programme using parasites as bioindicators is to ascertain changes in biodiversity at given locations. The comparison of the conditions in different habitats is helpful and necessary to understand the interactions of natural and anthropogenic processes, but these studies cannot replace long-term biomonitoring programmes. Only the latter can provide indications of the overall health of the environment (Winter and Hughes 1997).

MacKenzie et al. (1995) recommended a period of 25 years of data-gathering in each habitat before conclusions on the influence of pollutants can be deduced. By combining the results of biomonitoring assays and a careful use of data sampled, we will hopefully be able to reduce this period.
Biochemical and histochemical parameters

\section{Lipid accumulation/liver colour}

The pathological accumulation of neutral lipids in liver cell lysosomes is a well-known phenomenon, induced by, for example, chlorinated hydrocarbons. In an extensive review of the effects of pesticides on livers of fish, Couch (1975) reported that the most commonly encountered liver lesion was abnormal fatty accumulation, whereas flounder liver under normal conditions stores glycogen (Köhler 1990). Liver lipid accumulation may, therefore, be used as an indicator of contamination. Since the liver is responsible for the production of vitellogenin, the yolk protein precursor, the seasonal variation has to be taken into consideration when using the liver lipid content as a biomarker. Since several factors such as food supply, feeding behaviour and reproduction, especially in females, can influence the level of liver lipids, only intra- rather than inter-season comparisons between sampling sites are valid. Within the integrated biomarker approach, this parameter proved to be a useful tool for the quantification of pathologically induced liver deterioration.

Regarding the autumn campaigns 1995, 1996 and 1997, a significant increase in neutral lipid accumulation from 1995 to 1996 and 1997 at the locations Eider and Tiefe Rinne could be observed, corresponding to the increase of chlorinated hydrocarbons in fish tissue from these locations in 1997. Liver colour was positively correlated to total PCB and DDT metabolites in individual fish and can thus be regarded as a useful biomarker on its own.

\section{Lysosomal stability}

The lysosomal system of fish is sensitive to numerous environmental stimuli. Therefore, seasonal changes in lysosomal stability throughout the year are not surprising and have been previously reported for flounder by Köhler (1991). Despite the seasonal trends in lysosomal integrity, differences between sites remained consistent during the study. Animals from the most polluted location in the mouth of the river Elbe had the lowest lysosomal membrane stability during all seasons. In addition, an interesting finding was the significant decrease in lysosomal stability in the summer campaign, even in animals caught at the reference locations. An explanation for this phenomenon may be given through a seasonal dynamic change found in mussel lysosomes by Etxeberria et al. (1995). These authors found higher values of lysosomal volume, surface, size and numbers in the digestive gland of mussel in the summer. A direct association between the increase in lysosomal volume and membrane destabilisation in the digestive gland of mussel exposed to oil-derivated contaminants was observed by Lowe et al. (1981). An accumulation of unsatured neutral lipids in the lysosomes in combination with the 
increased fragility of the lysosomal membrane has also been described by Moore (1990) in mussels after exposure to contaminant chemicals. As observed in the present study, lysosomal stability reached its minimum in correlation with highest values of neutral lipids in summer. Even in fish from the reference locations, mean lysosomal stability values dropped below $10 \mathrm{~min}$, a value typical of Elbe fish, during autumn and spring campaigns. This represents a progressive liver cell damage potentially leading to the development of liver tumours, as described by Köhler (1991) in flounder of the German Bight. Thus, there appears to be a risk factor for fish inhabiting even the reference locations during the summer. Summer is the season of most intensive feeding. In an experimental study, Gardner et al. (1991) observed an uptake of parent PAH and PCBs by feeding winter flounder with contaminated blue mussels. Enhanced feeding may therefore be responsible for an increased uptake of xenobiotics.

Lysosomal stability values for female flounder from the Elbe and Eider locations of the present study are well in line with lysosomal stability data from 1991 and 1992 (Landwüst et al. 1996). In these years, mean Elbe values were $8.5 \mathrm{~min}$ (1991) and $6.5 \mathrm{~min}$ (1992), which is lower than the lysosomal stability measured in September 1995 in the present study (10 min), indicating an improvement in the contaminant situation in the Elbe. From summer 1996 to spring 1997, membrane stability dropped to mean values between 6 and $8 \mathrm{~min}$, indicating a deterioration in environmental conditions that was supported by the residue analysis (Fig. 1).

During the present study, three autumn and two spring campaigns were conducted. A decrease in lysosomal stability at the reference locations Eider and Tiefe Rinne in 1996 and 1997 compared to 1995 corresponded with an increase in organochlorine residues in fish tissue and elevated liver lipid accumulation and indicates the sensitivity of this biomarker to organic pollution. Lysosomal stability was negatively correlated with EROD activity as well as with the parasitological parameter of Trichodina infection intensity. Thus, of the biomarkers used in the present study it represents the most integrative parameter that reliably reflects site-specific differences, changes in time and the contaminant burden of the individual fish.

A negative correlation between lysosomal stability and heavy metal residues, as found in the mollusc Perna viridis by Cheung et al. (1998), could not be ascertained in the flounder during this study. In fact, the heavy metal concentrations, measured in flounder from the chosen locations, did not seem to have any effect on lysosomal stability.

\section{EROD activity}

EROD activity is known to be a sensitive indicator of the exposure to lipophilic compounds like PAHs, dioxins and coplanar PCB congeners (Goksøyr and Förlin 1992; Boer et al. 1993; Sleiderink et al. 1995). Seasonal varia- tion in EROD activity, due to the influence of the reproduction in female fish, as observed in the present study, has been described earlier for dab (Krüner et al. 1996) in the German Bight. During the reproductive season in the winter (November-February), relatively low EROD activity is generally measured in both sexes. Fish species that display an annual spawning cycle have demonstrated an estradiol-dependent suppression in expression of CYP1A activity and inducibility by polycyclic aromatic hydrocarbon-type inducers in gonadally mature female fish (Lindström-Seppä and Stegeman 1995). Outside the spawning season, EROD activity in flounder was relatively stable during the year, corresponding to the findings of Eggens et al. (1995) for flounder in the Dutch Wadden Sea. The high EROD activity in fish from Tiefe Rinne in April 1997 compared to April 1996, the corresponding increase in neutral lipid deposition, the decrease in lysosomal stability in the flounder liver and the results of the residue analysis indicate an increased chemical burden in spring 1997 at this location. Since EROD induction usually occurs shortly after the exposure to bioavailable aromatics (Stagg et al. 1998), the elevated activity values in spring 1997 in the Tiefe Rinne may be directly related to a pollution event that happened in the Elbe in 1995/1996, which is reflected in the high DDT values measured in Elbe fish in January 1996. Tiefe Rinne and Eider may have been affected by this event after a time lag only in spring 1997. From the above it can be confirmed that EROD activity can serve as a potent biomarker, provided it is not used during the productive season and it is used in conjunction with other biomarkers.

\section{Macrophage activity test}

The increase of acid phosphatase activity in macrophages is a well-known phenomenon accompanying the activation of macrophages in mammals (Klein 1991). In turbot, a highly significant correlation between reactive oxygen species (ROS) production, the standard marker of macrophage activation, and activity of acid phosphatase has been observed during exposure experiments (Broeg, in preparation). In this study, acid phosphatase activity in macrophage aggregates in the liver was used as a marker for macrophage activity to determine, whether there are differences in the activity of nonspecific immune response at different polluted locations.

The results of the present study indicate that the nonspecific immune response to environmental pollution differs with regard to male and female individuals. In female dab, the activity of macrophages in the liver is changing with maturity (Köhler and Broeg, unpublished data). Thus, not only environmental effects are influencing the MA activity in female individuals. The application of MA activity as a biomarker should therefore be restricted to male individuals. They show the clearest results when comparing different polluted locations. In addition, the correlation between chlorinated hydrocarbons, 
especially dieldrin, and the MA activity in male individuals is constantly negative, whereas in female flounder a positive correlation between MA activity and PCB 28 could be observed. In general, the use of immunological tests in bioeffect monitoring remains rather difficult, due to the fact that some chemicals act as immunosupressors while others may stimulate the immune response (Dunier and Siwicki 1993; Wester et al. 1994; Roszell and Anderson 1996).

MA activity displayed a close correlation with the size of the measured macrophage aggregates. Decreasing MA activity, which was found to be correlated with residues of dieldrin in male flounder liver, was in most cases accompanied by a small macrophage aggregate area (Broeg, unpublished data). This is in agreement with studies of Bucke et al. (1992) on dab spleen macrophages. In contrast, other studies showed contradicting results and found an increase in macrophage aggregate numbers in spleen and kidney following exposure to sewage sludge (Secombes et al. 1991).

Because of the complex functions of macrophages, and the different reactions of non-specific immune response, the activity of MA may not be used as a biomarker on its own. For the interpretation of the obtained results, background data, such as lysosomal stability and neutral lipid content of the liver, are needed in order to obtain information about the pathological status of the tested animal. Nevertheless, MA activity may serve as a link between the metabolic and parasitological data of one individual. As shown in Table 4, MA activity is correlated with all parameters, the parasitological as well as the biochemical and histochemical parameters, suggesting that the non-specific immune response may serve as the integrating part between the lowest and the highest levels of biological organisation.

\section{Conclusions}

Corresponding to the increase in chlorinated hydrocarbons in flounder muscle between September 1995 and January 1996, biochemical and histochemical biomarkers provided evidence of a pollution event. The existence of this event is confirmed by data provided by the Wassergütestelle Elbe (ARGE Elbe 1997), which reported a dramatic increase in DDT in the River Elbe in 1995 compared to the last 10 years of analytical evaluation. Residue analysis in flounder from all locations in spring 1997 indicated that Tiefe Rinne and Eider were affected by a time lag. Sediment analyses of April 1997 with higher values of specific organochlorines ( $\Sigma$ PCB, DDE and DDD) in Eider and Tiefe Rinne than in Elbe sediment confirm these findings (v. Westernhagen, unpublished data). All applied monitoring parameters reflected sensitivity to the effects of the increased chemical burden on flounder, not only in 1997 in the Tiefe Rinne, but also for all sampled locations starting in summer 1996. The occurrence of increased malformation rates in pelagic fish embryos from the southern
North Sea in early spring 1996 (Westernhagen and Dethlefsen 1997) provide further evidence of a pollution event in 1995/1996, which was detected by all biomarkers employed in the present study.

The following conclusions can be drawn from the present study: parasite species diversity, EROD activity and lysosomal stability did not actively affect each other but were probably affected by the same environmental conditions on a different time scale. A change in metabolic parameters occurred as a sudden reaction to deteriorating environmental factors. Following a chronic exposure to anthropogenic xenobiotics, a change in parasite diversity is probable. Thus, a combination of metabolic and parasitological data may serve as a sensitive tool for pollution monitoring.

For example, the high values of EROD activity and the high degree of neutral lipid accumulation in combination with decreased lysosomal membrane stability in April 1997 at Tiefe Rinne near Helgoland suggested that there was either a deterioration of the environmental factors or a massive migration of flounder from a polluted estuary to deeper waters. However, there was no significant difference in the composition of parasite species diversity between 1996 and 1997 or the spring campaigns in 1996 and 1997 in Tiefe Rinne fish. Therefore, the decline of the biochemical and histochemical parameters is actually a reflection of an environmental deterioration at an early stage. The combination of this array of bioindicators for pollution monitoring can therefore facilitate the interpretation of results against the background of natural and seasonal variation and provided valuable information about the stress level of individual fish.

Acknowledgements The authors would like to thank Angela Köhler for many helpful discussions and the opportunity to work in her laboratory. The technical assistance of Timo Kaminski, Sieglinde Bahns, Iris Kiesecker, Kerstin Böttcher and Heike Nachtweh is gratefully acknowledged. Last but not least, we thank Captain Lührs and the crew of the RV "Uthörn" for their neverending engagement in sampling flounder. This study was supported by the German Ministry of Education and Science (BMBF).

\section{References}

Andersson T, Pesonen M, Johansson C (1985) Differential induction of cytochrome P 450 dependent monooxygenase, epoxide hydrolase, glutathione transferase and UDP glucuronosyl transferase activities in the liver of the rainbow trout by $\beta$-NF or Clophen A50. Biochem Pharmacol 34:3309-3314

Anonymous (1996) Report of the Working Group on Biological Effects of Contaminants. ICES CM 1996, ENV 5, Ref E, pp $1-56$

ARGE Elbe (1997) 20 Jahre Arbeitsgemeinschaft für die Reinhaltung der Elbe. Wassergütestelle Elbe 23

Boer J, de Stronck CJN, Traag WA, van der Meer J (1993) Nonortho and mono-ortho substituted chlorobiphenyls and chlorinated dibenzo-p-dioxins and dibenzofurans in marine and freshwater fish and shellfish from the Netherlands. Chemosphere 26:1823-1842

Broeg K Activation of macrophage aggregates in the liver of turbot after treatment with $\beta$-naphtoflavone and organochlorines, in preparation 
Bucke D, Vethaak AD, Lang T (1992) Quantitative assessment of melanomacrophage centres (MMCs) in dab Limanda limanda along a pollution transect in the German Bight. Mar Ecol Prog Ser 91:193-196

Burke MD, Mayer RT (1974) Ethoxyresorufin: direct fluorimetric assay of a microsomal O-dealkylation which is preferentially inducible by 3-methyl-cholanthrene. Drug Metab Dispos 2:583-588

Burn PR (1980) Pollution effects on fish parasites. Coastal Ocean Pollut Assessment News 1:3-4

Bush AO, Lafferty KD, Lotz JM, Shostak AW (1997) Parasitology meets ecology on its own terms: Margolis et al. revisited. J Parasitol 83:575-583

Cheung VV, Wedderburn RJ, Depledge MH (1998) Molluscan lysosomal responses as a diagnostic tool for the detection of a pollution gradient in Tolo Harbour, Hong Kong. Mar Environ Res 46:237-241

Chieco P, Jonker A, Melchiorri C, Vanni G, Van Noorden CJF (1994) A user's guide for avoiding errors in absorbance image cytometry: a review with original experimental observations. Histochem J 26:1-19

Couch JA (1975) Histopathological effects of pesticides and related chemicals on the livers of fish. In: Ribelin WE, Migaki G (eds) The pathology of fish. Univ Wisconsin Press, Madison, pp 559-584

D'Amelio S, Gerasi L (1997) Evaluation of environmental deterioration by analysing fish parasite biodiversity and community structure. Parassitologia 39:237-242

den Besten PJ (1998) Concepts for the implementation of biomarkers in environmental monitoring. Mar Environ Res 46:253-256

Dey AC, Kicenuik JW, Williams UP, Khan RA, Payne JF (1983) Long term exposure of marine fish to crude petroleum. 1. Studies on liver lipids and fatty acids in cod (Gadus morhua) and winter flounder (Pseudopleuronectes americanus). Comp Biochem Physiol 75:93-101

Dunier M, Siwicki AK (1993) Effects of pesticides and other organic pollutants in the aquatic environment on immunity of fish: a review. Fish Shellfish Immunol 3:423-438

Eggens M, Bergman A, Vethaak D (1995) Seasonal variation of hepatic EROD activity in flounder (Platichthys flesus) in the Dutch Wadden Sea. Mar Environ Res 39:231-234

Etxeberria M, Cajaraville MP, Marigomez I (1995) Changes in digestive cell lysosomal structure in mussels as biomarkers of environmental stress in the Urdaibai estuary (Biscay Coast, Iberian Peninsula). Mar Pollut Bull 30:599-603

Gardner GR, Yevich PP, Harshberger JC, Russel Malcolm A (1991) Carcinogenecity of Black Rock Harbour sediments to the eastern oyster and trophic transfer of Black Rock Harbour carcinogens from the blue mussel to the winter flounder. Environ Health Perspect 90:53-66

Gelnar M, Sebelová S, Dusek L, Koubovká B, Jurajda P, Zahrádková S (1997) Biodiversity of parasites in freshwater environment in relation to pollution. Parassitologia 39:189199

Gibson DI (1972) Contributions to the life-history and development of Cucllanellus minutus and Cucullanus heterochrous. Bulletin of the British Museum. Nat Hist Zool 22:153-170

Goksøyr A, Förlin L (1992) The cytochrome P450 system in fish, aquatic toxicology and environmental monitoring. Aquat Toxicol 22:287-312

Hileman B (1993) Concerns broaden over chlorine and chlorinated hydrocarbons. Chem Eng News, 19 April 1993, 11-20

ICES (1984) The ICES co-ordinated monitoring programme for contaminants in fish and shellfish 1978 and 1979 and six year review of ICES co-ordinated monitoring programme. Coop Res Rep 126:1-100

Janiszewska J (1938) Studien über die Entwicklung der parasitischen Würmer in der Flunder. Mem Acad Polon Sci Lettr Ser B, 1:1-64

Kennedy CR (1997) Freshwater fish parasites and environmental quality: an overview and caution. Parassitologia 39:248-254
Khan RA (1987) Crude oil and parasites of fish. Parasitol Today 3:99-100

Khan RA (1990) Parasitism in marine fish after chronic exposure to petroleum hydrocarbons in the laboratory and to the Exon Valdez oil spill. Bull Environ Contam Toxicol 44:759-763

Khan RA (1994) Influence of crude oil and pulp and paper mill effluent on mixed infections of Trichodina cottidarium and $T$. saintjohnsi (Ciliophora) parasitizing Myoxocephalus octodecemspinosus and M. scorpius. Can J Zool 72:247-251

Khan RA, Kiceniuk J (1983) Effects of crude oil on the gastrointestinal parasites of two species of marine fish. J Wildl Dis 19:253-258

Khan RA, Payne JF (1997) A multidisciplinary approach using several biomarkers, including a parasite, as indicators of pollution: a case history from a paper mill in Newfoundland. Parassitologia 39:183-188

Klein J (1991) Immunologie. VHC, Weinheim, pp 1-534

Köhler A (1990) Identification of contaminant-induced cellular and subcellular lesions in the liver of flounder (Platichthys flesus L.) caught at differently polluted estuaries. Aquat Toxicol 16:271-294

Köhler A (1991) Lysosomal perturbations in fish liver as indicators for toxic effects of environmental pollution. Comp Biochem Physiol (C) 100:123-127

Krüner G, Jansen D, v Westernhagen H (1996) Wissenschaftliche Grundlagen sowie Beschaffung und Bewertung von Daten für das Biologische Monitoring der Nordsee. Ber Biol Anst Helgoland 11:1-82

Kruse R, Krüger K (1984) Untersuchungen von Nordseefischen auf Gehalte an toxischen Schwermetallen und chlorierten Kohlenwasserstoffen im Hinblick auf lebensmittelrechtliche Bestimmungen. Arch Lebensmittelhyg. 35:128-131

Lafferty KD (1997) Environmental parasitology: what can parasites tell us about human impacts on the environment? - Parasitol Today 13:251-255

Landwüst C v, Anders K, Holst S et al. (1996) Fischkrankheiten in der Nordsee. Umweltbundesamt Texte 57/96, ISSN 0722186X, 1-557

Lindström-Seppä P, Stegeman JJ (1995) Sex differences in cytochrome P4501A induction by environmental exposure and $\beta$ naphthoflavone in liver and extrahepatic organs of recrudescent winter flounder. Mar Environ Res 39:219-223

Lojda Z, Gossrau R, Schiebler Th (1976) Enzymhistochemische Methoden. Springer, Berlin Heidelberg New York, pp 7273

Lotz JM (1997) Quantitative aspects of evaluating the consequences of pollution for parasite populations and communities. Parassitologia 39:243-248

Lowe DM, Moore MN, Clarke KR (1981) Effects of oil on digestive cells in mussels: quantitative alterations in cellular and lysosomal structure. Aquat Toxicol 1:213-226

Lowry OH, Rosebrough NJ, Farr AL, Randall RJ (1951) Protein measurement with the folin phenol reagent. J Biol Chem 193:265-275

MacKenzie K, Gibson DI (1970) Ecological studies of some parasites of plaice and flounder. In: Taylor AER (ed) Aspects of fish parasitology. Blackwell, Oxford

MacKenzie K, Williams HH, Williams B, McVicar AH, Siddall R (1995) Parasites as indicators of water quality and the potential use of helminth transmission in marine pollution studies. Adv Parasitol 35:86-144

Möller H (1974) Untersuchungen über die Parasiten der Flunder (Platichthys flesus L.) in der Kieler Förde. Ber Dtsch Wiss Kommn Meeresforsch 23:136-149

Moore MN (1990) Lysosomal cytochemistry in marine environmental monitoring. Histochem J 22:187-191

National Academy of Sciences (1990) Managing troubled waters: the role of marine environmental monitoring. National Academy Press, Washington, DC

Nilson F (1995) Description of Trichodina hippoglossi n.sp. from farmed Atlantic halibut Hippoglossus hippoglossus. Dis Aquat Org 21:209-214 
Overstreet RM (1997) Parasitological data as monitors of environmental health. Parassitologia 39:169-175

Overstreet RM, Howse HD (1977) Some parasites and diseases of estuarine fish in polluted habitats of Mississippi. Annu Rep N Y Acad Sci 298:427-462

Poulin P (1992) Toxic pollution and parasitism in freshwater fish. Parasitol Today 8:58-61

Roszell IF, Anderson RS (1996) Effect of chronic in vivo exposure to pentachlorophenol on non-specific immune functions in Fundulus heteroclitus. Mar Environ Res 42:191-194

Secombes CJ, Fletcher TC, O'Flynn JA, Costello MJ, Staff R, Houlihan DF (1991) Immunocompetence as a measure of the biological effects of sewage sludge pollution in fish. Comp Biochem Physiol 100:133-136

Skinner RH (1982) The interrelation of water quality, gill parasites and gill pathology of some fishes from South Biscayne Bay, Florida. J Fish Biol 80:269-280

Sleiderink HM, Everaarts JM, Goksoyr A, Boon JP (1995) Hepatic cytochrome P450 1A induction in dab (Limanda limanda) after oral dosing with the polychlorinated biphenyl mixture Chlophen A40. Environ Toxicol Chem 14:679-687

Stagg RM, Robinson C, McIntosh AM, Moffat CF, Bruno DW (1998) The effects of the Braer oil spill, Shetland Isles, Scotland, on P4501A in farmed Atlantic salmon (Salmo salar) and the common dab (Limanda limanda). Mar Environ Res 46:301-306
Sulgostowska T (1988) Changes in the parasite fauna of the flounder Platichthys flesus dependent on the degree of pollution of the south-western Baltic Sea. Wiad Parazytol 34:591594

Vethaak AD, Wester PW (1996) Diseases of flounder (Platichthy flesus) in Dutch coastal and estuarine waters, with particular reference to environmental stress factors. 2. Liver histopathology. Dis Aquat Org 26:99-116

Wahl E, Cameron P, Köhler-Günther A et al. (1995) Fischkrankheiten im Wattenmeer. Umweltbundesamt Texte 51/95, ISSN 0722-186X, 1-216

Wester PW, Vethaak AD, Muiswinkel van WB (1994) Fish as biomarkers in immunotoxicology. Toxicology 86:213-232

Westernhagen H v, Dethlefsen V (1997) The use of malformations in pelagic fish embryos for pollution assessment. Hydrobiologica 352:241-250

Winter B, Hughes RM (1997) Biodiversity. American Fisheries Society Position Statement. Fisheries 22:16-23

Wolfe DA (1992) Selection of bioindicators of pollution for marine environmental monitoring programmes. Chem Ecol 6:149-167

Yeomans WE, Chubb JC, Sweeting RA (1997) Use of protozoan communities for pollution monitoring. Parassitologia 39:201212

Communicated by H. v. Westernhagen

\section{Appendix}

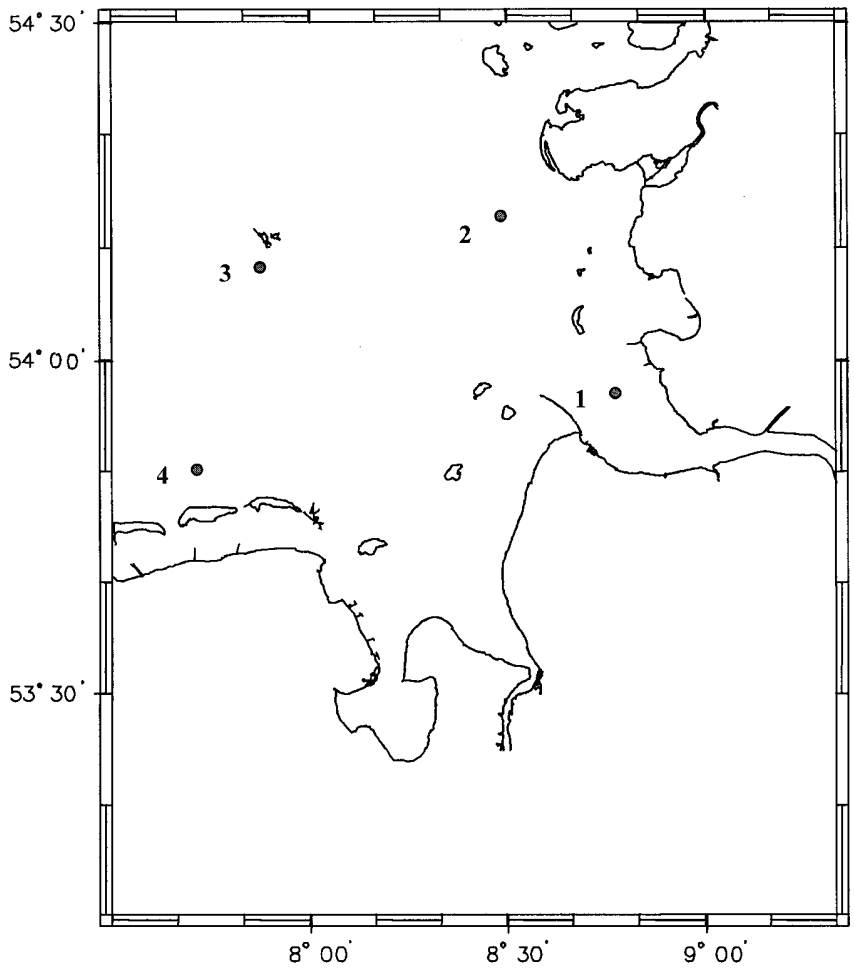

Map 1 Map of sampled North Sea stations:

1. Elbe estuary

2 . Eider estuary

3. Tiefe Rinne/Helgoland

4. Spiekeroog 